\title{
AN INTRODUCTION TO STAPHYLOCOCCUS AUREUS, AND TECHNIQUES FOR IDENTIFYING AND QUANTIFYING $S$. AUREUS ADHESINS IN RELATION TO ADHESION TO BIOMATERIALS: REVIEW
}

\author{
L.G. Harris ${ }^{1,2 *}$, S.J. Foster ${ }^{2}$, and R.G. Richards ${ }^{1}$ \\ ${ }^{1}$ AO Research Institute, Clavadelerstrasse, CH 7270 Davos, Switzerland; ${ }^{2}$ Dept. Molecular Biology and \\ Biotechnology, University of Sheffield, Firth Court, Sheffield, S10 2TN, UK.
}

\begin{abstract}
The ability of Staphylococcus aureus to adhere to the extracellular matrix and plasma proteins deposited on biomaterials is a significant factor in the pathogenesis of orthopaedic-device related infections. S. aureus possesses many adhesion proteins on its surface, but it is not known how they interact with each other to form stable interactions with the substrate.

A novel method was developed for extracting adhesins from the $S$. aureus cell wall, which could then be further analysed. The protocol involves using a FastPrep instrument to mechanically disrupt the cell walls resulting in native cell walls. Ionically and covalently bound proteins were then solubilised using sodium dodecyl sulphate (SDS) and lysostaphin, respectively. Western blot analysis of covalently bound proteins using anti-protein $\mathrm{A}$ and anticlumping factor A sera showed that $S$. aureus produces most surface proteins in early growth, and less in postexponential and stationary growth.

Immuno-gold labelling of protein A, and clumping factor A was observed all over the bacteria and showed no distinct surface distribution pattern. However, this labelling showed expression of surface associated proteins varied in a growth-phase dependent and cell-density dependent manner.
\end{abstract}

Key Words: Staphylococcus aureus, infection, adhesin, surface protein, resistance, biomaterials.

*Address for correspondence:

Llinos Harris

AO Research Institute

Clavadelerstrasse, CH 7270 Davos, Switzerland

E-mail: 1linos.harris@ao-asif.ch

\section{Introduction}

\section{The Staphylococci}

Staphylococci are Gram-positive bacteria, with diameters of $0.5-1.5 \mu \mathrm{m}$ and characterised by individual cocci, which divide in more than one plane to form grape-like clusters. To date, there are 32 species and eight sub-species in the genus Staphylococcus, many of which preferentially colonise the human body (Kloos and Bannerman, 1994), however Staphylococcus aureus and Staphylococcus epidermidis are the two most characterised and studied strains.

The staphylococci are non-motile, non-spore forming facultative anaerobes that grow by aerobic respiration or by fermentation. Most species have a relative complex nutritional requirement, however, in general they require an organic source of nitrogen, supplied by 5 to 12 essential amino acids, e.g. arginine, valine, and B vitamins, including thiamine and nicotinamide (Kloos and Schleifer, 1986; Wilkinson, 1997). Members of this genus are catalase-positive and oxidase-negative, distinguishing them from the genus streptococci, which are catalase-negative, and have a different cell wall composition to staphylococci (Wilkinson, 1997). Staphylococci are tolerant to high concentrations of salt (Wilkinson, 1997) and show resistance to heat (Kloos and Lambe 1991). Pathogenic staphylococci are commonly identified by their ability to produce coagulase, and thus clot blood (Kloos and Musselwhite, 1975). This distinguishes the coagulase positive strains, $S$. aureus (a human pathogen), and S. intermedius and S. hyicus (two animal pathogens), from the other staphylococcal species such as $S$. epidermidis, that are coagulase-negative (CoNS).

\section{Staphylococcus aureus}

Staphylococcus aureus is a major pathogen of increasing importance due to the rise in antibiotic resistance (Lowy, 1998). It is distinct from the CoNS (e.g. S. epidermidis), and more virulent despite their phylogenic similarities (Waldvogel, 1990; Projan and Novick, 1997). The species named aureus, refers to the fact that colonies (often) have a golden colour when grown on solid media, whilst CoNS form pale, translucent, white colonies (Howard and Kloos, 1987). To date the $S$. aureus genome databases have been completed for 7 strains, 8325, COL, MRSA, MSSA, N315, Mu50, and MW2 (Web ref. 1-6). The average size of the $S$. aureus genome is $2.8 \mathrm{Mb}$ (Kuroda et al., 2001).

The cell wall of $S$. aureus is a tough protective coat, which is relatively amorphous in appearance, about 20$40 \mathrm{~nm}$ thick (Shockman and Barrett, 1983). Underneath the cell wall is the cytoplasm that is enclosed by the cyto- 
plasmic membrane. Peptidoglycan is the basic component of the cell wall, and makes up $50 \%$ of the cell wall mass (Waldvogel, 1990). It is integral in the formation of the tight multi-layered cell wall network, capable of withstanding the high internal osmotic pressure of staphylococci (Wilkinson, 1997). Another cell wall constituent is a group of phosphate-containing polymers called teichoic acids, which contribute about $40 \%$ of cell wall mass (Knox and Wicken, 1973). There are two types of teichoic acids, cell wall teichoic acid and cell membrane associated lipoteichoic acid; bound covalently to the peptidoglycan or inserted in the lipid membrane of the bacteria. Teichoic acids contribute a negative charge to the staphylococcal cell surface and play a role in the acquisition and localisation of metal ions, particularly divalent cations, and the activities of autolytic enzymes (Wilkinson, 1997). Peptidoglycan and teichoic acid together only account for about $90 \%$ of the weight of the cell wall, the rest is composed of surface proteins, exoproteins and peptidoglycan hydrolases (autolysins). Some of these components are involved in attaching the bacteria to surfaces and are virulence determinants. Finally, over $90 \%$ of $S$. aureus clinical strains have been shown to possess capsular polysaccharides (Karakawa and Vann, 1982; Thakker et al., 1998). Capsule production is reported to decrease phagocytosis in vitro, and to enhance $S$. aureus virulence in a mouse bacteraemia model (Wilkinson and Holmes, 1979; Thakker et al., 1998), therefore acting as a form of biofilm.

The growth and survival of bacteria is dependent on the cells ability to adapt to environmental changes. $S$. aureus has evolved many mechanisms to overcome such changes, particularly in an infection. A growth curve of $S$. aureus grown under ideal conditions can be divided into three phases: lag, exponential, and stationary, as shown in Figure 1. During exponential phase, bacterium metabolism is rapid and efficiently to ensure constant growth. As the bacteria age and stop growing (post-exponential), cellular metabolism is re-organised for long-term survival under unfavourable conditions.

$S$. aureus has three well characterised global regulators of virulence determinant production, agr (Recsei et al., 1986; Morfeldt et al., 1988), sar (Cheung et al., 1992), and sae (Giraudo et al., 1994) that regulate the expression of surface proteins, exoproteins, and other proteins essential for growth. Studies have shown that the accessory gene regulator $(a g r)$ up-regulates the production of many exoproteins, including TSST-1, enterotoxin B and $\mathrm{C}$, and V8 protease $(\operatorname{ssp} A)$; and down-regulates the synthesis of cell wall associated proteins, including fibronectin-binding proteins, and fibrinogen-binding proteins during post-exponential and stationary growth phase (Foster et al., 1990; Lindberg et al., 1990).

Cheung et al. (1992) identified a second regulatory locus called staphylococcal accessory regulator $(\operatorname{sar} A)$, and is distinct from the agr locus. A sarA mutant decreases the expression of several exoproteins, such as $\alpha-, \beta$-, and $\delta$-haemolysin, and increases others such as proteases (Cheung et al., 1994; Chan and Foster, 1998). Studies have also shown that sarA is essential for agr-dependent regulation (Heinrichs et al., 1996; Lindsay and Foster,

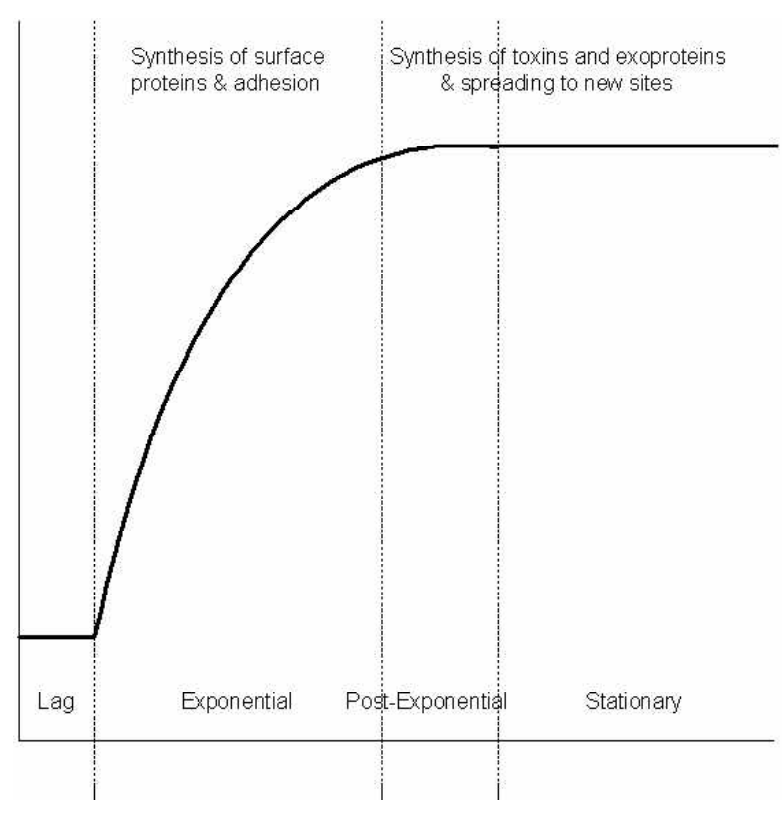

Figure 1. Model of virulence factor production in staphylococcal infections. In lag phase, bacteria initiate an infection, then enter exponential phase where they multiply and synthesise surface proteins and essential proteins for growth, cell division and adhesion. During post-exponential, crowding activates a density sensing mechanism, resulting in the production of toxins and exoproteins. This enables the bacteria to escape from the localised infection (abscess) during stationary phase and spread to new sites, where the cycle is repeated.

1999). A double mutant, agr sarA was found to decrease the expression of exoproteins and cell wall-associated proteins compared to single agr and sarA mutants (Cheung et al., 1992). The release of the S. aureus genome has led to the discovery of additional genes with homology to sarA. These include sarH1 (also known as sarS; Tegmark et al., 2000; Cheung et al., 2001) and sarT (Schmidt et al., 2001). The expression of sarH1 is regulated by sarA and agr (Tegmark et al., 2000), and is transcribed, as is sarA by SigA- and SigB-dependent promoters (Deora at al, 1997; Manna et al., 1998).

A further locus, sae ( $S$. aureus exoprotein expression) has been identified and shown to have a role in the production of virulence determinants (Giraudo et al., 1994). It has subsequently been shown to be different from the agr and sarA loci (Giraudo et al., 1999). An sae mutant caused a decrease in the production of $\alpha$ - and $\beta$ haemolysin, DNase, coagulase and protein A (Giraudo et al., 1994). However, no differences in the production levels of d-haemolysin, proteases, and lipase were observed. Giraudo et al. (1997) revealed by Northern blot that sae affects exoprotein expression at the transcriptional level.

The regulation of virulence determinants may also involve sigma factors $(\sigma)$, which are proteins that bind to the core RNA polymerase to form the holoenzyme that binds to specific promoters (Moran, 1993; Deora and Misra, 1996). In $S$. aureus there are two sigma factors: 
$\sigma^{\mathrm{A}}$, the primary sigma factor responsible for the expression of housekeeping genes, whose products are necessary for growth (Deora et al., 1997); and $\sigma^{\mathrm{B}}$, the alternative sigma factor, that regulates the expression of many genes involved in cellular functions (Deora and Misra, 1996). $\sigma^{\mathrm{B}}$ has a role in virulence determinant production, and stress response (Horsburgh et al., 2002).

\section{$S$. aureus cell wall associated surface proteins}

The ability of $S$. aureus to adhere to plasma and extracellular matrix (ECM) proteins deposited on biomaterials is a significant factor in the pathogenesis of device-associated infections. Several specific adhesins are expressed on the surface of $S$. aureus, which interact with a number of host proteins, such as fibronectin, fibrinogen, collagen, vitronectin and laminin (Foster and McDevitt, 1994), and have been designated MSCRAMMs (microbial surface components recognising adhesive matrix molecules) (Patti et al., 1994). The biological importance of MSCRAMMs and their roles as virulence determinants are still being elucidated.

To be classed as a MSCRAMM, the molecule of interest must be localised to the bacteria cell surface, and must recognise a macromolecule ligand found within the host's ECM. These ligands include molecules such as collagen and laminin, which are found exclusively in the ECM, and others such as fibrinogen and fibronectin, that are part-time ECM molecules but are also found in soluble forms such as blood plasma (Patti et al., 1994). The interaction of MSCRAMMs and the ECM should be of high affinity and specificity. Numerous bacteria have been shown to bind a variety of ECM components, some of which have not been identified or characterised at the molecular level. A single MSCRAMM can bind several ECM ligands, whilst bacteria such as $S$. aureus can express several MSCRAMMs that recognise the same matrix molecule (Boden and Flock, 1989; McDevitt et al., 1994). This type of variation and interactions resemble the ones between eukaryotic integrins and matrix molecules, in which the integrin can bind several different ligands, and one particular ligand may be recognised by several integrins (Ruoslahti, 1991).

Many cell wall associated surface proteins of Grampositive bacteria can be identified by analysis of primary amino acid sequences. At the $\mathrm{N}$-terminal approximately 40 amino acids are required for Sec-dependent protein secretion, and the C-terminal contains a wall-spanning domain, rich in proline and glycine residues or composed of serine-aspartate dipeptide repeats, an leucine-prolineX-threonine-glycine (LPXTG) motif and a hydrophobic membrane-spanning domain followed by a series of positively charged residues (Schneewind et al., 1995). The ligand binding functions are often located in the N-terminal domain (Patti et al., 1994). Most MSCRAMMs have an LPXTG motif, which is cleaved between the threonine and glycine by sortase (Navarre et al., 1998; Mazmanian et al., 2001). In S. aureus, the carboxyl group of threonine is covalently bound to the carboxyl group of a pentaglycine sequence in the peptidoglycan (Ton-That et al., 1997). Hence, the $\mathrm{N}$-terminal ligand binding domain is covalently linked to the cell wall peptidoglycan and can only be released from the cell wall by cleavage with the muralytic enzyme, lysostaphin (Schindler and Schuhardt, 1964). Several proteins have been found to be covalently bound to the insoluble cell wall peptidoglycan in $S$. aureus via the sortase-catalysed pathway (Navarre and Schneewind, 1999; Mazmanian et al., 2001).

Several in vitro studies have demonstrated that these adhesins (or MSCRAMMs) promote $S$. aureus attachment to each of the mentioned plasma or ECM proteins individually adsorbed onto polymer or metal surfaces. Several proteins have been characterised biochemically and their genes sequenced, include protein $\mathrm{A}$, fibrinogen binding protein, fibronectin binding protein, and collagen binding protein (François et al., 1996). There are many more such adhesins on the surface of $S$. aureus, which have yet to be identified and characterised.

\section{$S$. aureus associated infections}

$S$. aureus is considered to be a major pathogen that colonises and infects both hospitalised patients with decreased immunity, and healthy immuno-competent people in the community. This bacterium is found naturally on the skin and in the nasopharynx of the human body. It can cause local infections of the skin, nose, urethra, vagina and gastrointestinal tract, most of which are minor and not life-threatening (Shulman and Nahmias, 1972). Over 4\% of patients admitted into one of 96 hospitals in England between 1997 and 1999 for surgery acquired a nosocomial infection, which is defined as an infection where there was no evidence the infection was present or incubating prior to hospitalisation (Central Public Health Laboratory, UK, 2000). The environment within a hospital also supports the acquisition of resistant $S$. aureus strains. The same study found $81 \%$ of the infections were caused by $S$. aureus, and $61 \%$ of these were methicillin resistant.

The skin and mucous membrane are excellent barriers against local tissue invasion by $S$. aureus. However, if either of these is breached due to trauma or surgery, $S$. aureus can enter the underlying tissue, creating its characteristic local abscess lesion (Elek, 1956), and if it reaches the lymphatic channels or blood can cause septicaemia (Waldvogel, 1990). The basic skin lesion caused by an $S$. aureus infection is a pyogenic abscess. However, $S$. aureus can also produce a range of extracellular toxins, such as enterotoxin A-E, toxic shock syndrome toxin1 (TSST-1) and exfoliative toxins A and B (Projan and Novick, 1997). Ingestion of enterotoxin produced by $S$. aureus in contaminated food can cause food poisoning (Howard and Kloos, 1990). TSST-1 is the toxin responsible for toxic shock syndrome (TSS) and is only caused by strains carrying the TSST-1 gene (Waldvogel, 1990). TSS infections are commonly associated with menstruating women, particularly those using tampons. The exfoliative toxins are associated with staphylococcal scalded skin syndrome (SSSS). SSS consists of three entities, toxic epidermal necrolysis, scarlatiniform erythema, and bullous impetigo (Howard and Kloos, 1987), all of which damage the epidermal layer of the skin.

To date, infection rates following orthopaedic surgery are 1-2\% for total hip arthroplasty (Sanderson, 1991); $4 \%$ for total knee arthroplasty (Walenkamp, 1990); 2-25\% 
for open fractures (Gustilo et al., 1990); and $1.5 \%$ for closed fractures (Boxma, 1995). S. aureus has been found to be a common cause of metal-biomaterial, bone-joint and soft-tissue infections (Petty et al., 1985; Barth et al., 1989). The implantation of biomaterial into the human body, and the damage caused is known to increase the susceptibility to infection (Elek and Conen, 1957), and activates host defences, stimulating the release of inflammatory mediators, including oxygen radicals and lysosomal enzymes (Merritt and Dowd, 1987; Dickinson and Bisno, 1989; Gristina, 1994). The fate of a biomaterial surface may be conceptualised as a "race for the surface", involving ECM, host cells and bacteria (Gristina, 1987). Once biomaterial implants are implanted they are coated with host plasma constituents, including ECM (Baier et al., 1984). If host cells, such as fibroblasts arrive at the biomaterial surface and secure bonds are established, bacteria are confronted by a living, integrated cellular surface. Such an integrated viable cell layer with functional host defence mechanisms can resist $S$. aureus attachment (Gristina, 1987). However, S. aureus possesses a variety of adhesion mechanisms, such as MSCRAMMs, that facilitates their adhesion to biomaterials, and to the ECM proteins deposited on the biomaterial surface (Herrmann et al., 1993). Once $S$. aureus attach to a surface, host cells are unable to dislodge them (Gristina, 1994). Gross et al. (2001), demonstrated that teichoic acids on the S. aureus cell wall carry a negative charge, and have a key role in the first step of biofilm formation.

Biofilm formation is a two-step process that requires the adhesion of bacteria to a surface followed by cell-cell adhesion, forming multiple layers of the bacteria (Cramton et al., 1999). Once a biofilm has formed, it can be very difficult to clinically treat because the bacteria in the interior of the biofilm are protected from antibiotics and phagocytosis (Hoyle and Costerton, 1991). Virulence factors such as proteases are produced once $S$. aureus has colonised a surface (Peterson et al., 1977).

There are also a number of implant-related factors that influence the susceptibility to infection. These include the size and shape of the implant (Melcher et al., 1994), the technique and stability of the implant (Worlock et al., 1994), surface characteristics (Gristina, 1987; Cordero et al., 1994), and the material and its biocompatibility (Gerber and Perren, 1980; Petty et al., 1985).

Biomaterial surfaces usually have a negative charge and initially repel the negatively charged bacteria. However, at a distance of around $15 \mathrm{~nm}$, van der Waals and hydrophobic forces are exerted and repulsion is overcome (Pashley et al., 1985; Gristina, 1987). At distances of around $1 \mathrm{~nm}$, short-range chemical interactions (ionic, hydrogen, and covalent bonding) occur between the biomaterial and the host cells or bacteria, as shown in Figure 2 (Gristina, 1987). This is the reaction that occurs between receptors on the ECM and those on the bacterial cell wall.

The factors that influence the interaction and adhesion between living cells and biomaterials and between bacteria and biomaterials are the two most important components of biocompatibility (Stickler and McLean, 1995).

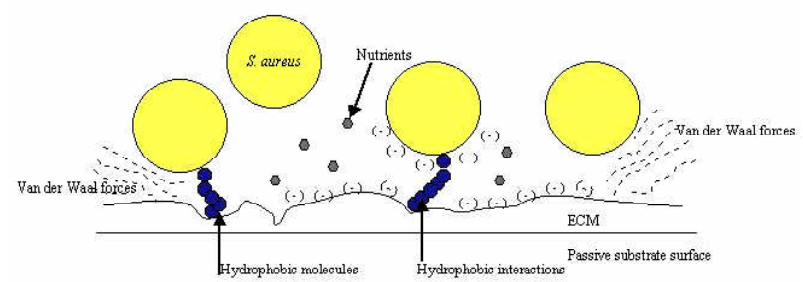

Figure 2 Schematic diagram showing the interactions that occur during the attachment of bacteria to a substrate surface. At specific distances the initial repelling forces between like charges (-) on the surfaces of bacteria and substrate are overcome by attracting van der Waals forces (-), and the hydrophobic interactions between molecules (blue circles). Under appropriate conditions the ECM is laid down, allowing ligand-receptor interaction and attachment of the bacteria to the substrate (based on image by Gristina et al., 1985).

All biomaterial surfaces in a biological environment acquire a conditioning film of ECM proteins. The ECM is a biologically active tissue composed of complex mixture of macromolecules, such as fibronectin, fibrinogen, albumin, vitronectin, and collagen. Eukaryotic cell adhesion, migration, proliferation and differentiation are all influenced by the composition and structural organisation of the surrounding ECM (Ruoslahti, 1991). It is known that interaction between eukaryotic cells and the ECM is mediated by specific receptors such as integrins. Integrins are composed of a and b units, and link many ECM proteins to the cellular cytoskeleton (Ruoslahti, 1991). However, the ECM not only serves as a substrate for host cells but also for the attachment of colonising bacteria. Over the years, many bacterial surface adhesins have been identified that are expressed by bacteria, e.g. S. aureus, that promote attachment to plasma and ECM proteins of host cells or those adsorbed onto polymer or metal surfaces (François et al., 1996). Gristina's (1994) studies on the interaction of the ECM proteins and the biomaterial surface, found a tendency for lateral molecule-to-molecule interaction, creating reticulated island-like arrangements of non-confluent protein molecules on the surface. Hence, the ECM is a dynamic layer of varying thickness, interspaced with non-coated surfaces.

Stainless steel and titanium are the most commonly used material for osteosynthesis implants, and the differences between the two metals are well documented (Perren, 1991; Chang and Merrittt, 1994; Melcher et al., 1994; Arens et al., 1996). Stainless steel implants are associated with significantly greater infection rates than titanium implants (Melcher et al., 1994; Arens et al., 1996). A possible reason for this is the fact that soft tissue adheres firmly to titanium implant surfaces (Gristina, 1987; Perren, 1991), whilst a known reaction to steel implants is the formation of a fibrous capsule, enclosing a liquid filled void within (Woodward and Salthouse, 1986; Gristina, 1987). Bacteria can spread and multiply freely in this unvascularised space, which is also less accessible 
to the host defence mechanisms. Therefore, the key to the "race for the surface" is to have a biomaterial implant with good biocompatibility with the host cells, optimal adhesion characteristics to reduce capsule formation, and a surface that discourages cellular hyper-inflammatory responses (Perren, 1991; Gristina, 1994). Biocompatibility is normally considered to involve four separate inter-related components; (1) the adsorption of proteins and other macromolecules on the surface of the material; (2) the changes induced in the material by the host; (3) the effects of the material on the local tissues of the host; and (4) the effects of the implant on the host systemically or remotely (Williams, 1989).

\section{Treatment of $\boldsymbol{S}$. aureus infections}

The excessive use of antibiotics has led to the emergence of multiple drug resistant $S$. aureus strains (Lowy, 1998). Penicillin was introduced for treating $S$. aureus infections in the 1940s, and effectively decreased morbidity and mortality. However, by the late 1940 s, resistance due to the presence of penicillinase emerged (Eickhoff, 1972). The staphylococci are very capable of evolving resistance to the commonly used antimicrobial agents, such as, erythromycin (Wallmark and Finland, 1961), ampicillin (Klein and Finland, 1963), and tetracycline (Eickhoff, 1972). In most cases, resistance to antibiotics is coded for by genes carried on plasmids, accounting for the rapid spread of resistant bacteria (Morris et al., 1998). Soon after the introduction of methicillin, Jevons (1961) described the emergence of methicillin resistant S. aureus (MRSA), which have since spread worldwide as nosocomial pathogens. The Central Public Health Laboratory, UK (2000) found that $61 \%$ of nosocomial $S$. aureus infections in the 96 hospitals studied were methicillin resistant.

Penicillin, a ß-lactam antibiotic works by inhibiting bacterium cell wall synthesis by inactivating the penicillin-binding proteins (PBP). MRSA strains produce a distinct $\mathrm{PBP}$, designated $\mathrm{PBP} 2^{\prime}$, which has a low affinity to B-lactam antibiotics, hence PBP2/ can still synthesise the cell wall in the presence of the antibiotic (Hiramatsu, 1995). This is the basis for ß-lactam resistance in MRSA strains. $\mathrm{PBP} 2$ are products of the gene mecA, which is located in $m e c$, foreign chromosomal DNA found in methicillin resistant strains but not in methicillin susceptible strains (Hiramatsu et al., 1997). Vancomycin, a glycopeptide has been the most reliable antibiotic against MRSA infections; however, in 1996 the first MRSA to acquire vancomycin intermediate resistance was isolated in Japan (Hiramatsu et al.,1997). Unfortunately, several vancomycin insensitive $S$. aureus (VISA) strains have been reported in the USA, France, Scotland, Korea, South Africa and Brazil (Hiramatsu, 2001). Upon exposure to vancomycin, certain MRSA strains frequently generate VISA strains, called hetero-VISA (Hiramatsu, 2001). VISA resistance appears to be associated with thickening of the cell wall peptidoglycan, and due to an increase in the target for the glycopeptide in the cell wall, therefore requiring more glycopeptide to inhibit the bacteria from growing (Hanaki et al., 1998). All VISA strains isolated appear to have a common mechanism of resistance, which differs from that found in vancomycin resistant entero- cocci, in that enterococcal van genes are not present (Walsh, 1993). However in 2002, the first vancomycin resistant $S$. aureus (VRSA) infection was documented in a patient in the United States (Sievert et al., 2002). This strain was shown to carry a van gene, suggesting that the resistance determinant might have been acquired through the genetic exchange of material between vancomycin resistant enterococci and $S$. aureus. The spread of vancomycin resistance worldwide is now inevitable, and could potentially result in a return to pre-antibiotic era. Hence, the identification of novel targets on the bacteria seems to be a pre-requisite in the search for new antibiotics and prophylaxis, e.g. vaccines.

\section{Aim of study}

The aim of this work was to develop an efficient method for identifying and quantifying $S$. aureus adhesins, such as protein $\mathrm{A}$ and clumping factor $\mathrm{A}$. In order to identify such cell wall associated proteins, a novel method of extracting proteins was used. Immuno-gold labelling was also used to assist in the visualisation and quantification of the adhesins.

\section{Materials and Methods}

\section{Bacterial maintenance and culturing}

Strains of $S$. aureus (listed in Table 1) were streaked from glycerol stocks onto brain heart infusion (BHI) medium plates containing relevant antibiotics, grown overnight at $37^{\circ} \mathrm{C}$ and subsequently used to inoculate $100 \mathrm{ml}$ prewarmed BHI (containing no antibiotics) in $250 \mathrm{ml}$ conical flasks. Pre-cultures were grown to mid-exponential phase at $37^{\circ} \mathrm{C}$ in a shaking water bath at 250 r.p.m. for 3 $\mathrm{h}\left[\mathrm{OD}_{600} \sim 1\right.$; Jenway (Dunmow, Essex, UK) $6100 \mathrm{spec}-$ trophotometer] and used to inoculate $100 \mathrm{ml}$ pre-warmed BHI (same batch as pre-culture, no antibiotics) in test flasks $(250 \mathrm{ml})$ to a starting $\mathrm{OD}_{600}$ of 0.05 and again incubated as above. Samples were taken after $2 \mathrm{~h}, 4 \mathrm{~h}, 8 \mathrm{~h}$, and $18 \mathrm{~h}$. These time points represent mid-exponential, postexponential, early and late stationary phases respectively (Fig. 3).

\section{Novel method for the extraction of cell wall associated proteins}

From $100-300 \mathrm{ml}$ of culture, cells were harvested by centrifugation $\left(8,000 \times \mathrm{g}, 5 \mathrm{~min}, 4^{\circ} \mathrm{C}\right)$. The pellet was then resuspended in $1 \mathrm{ml}$ cold Tris buffered saline (TBS). The cells were recovered by centrifugation $(8,000 \mathrm{x}$ g, $5 \mathrm{~min}$, $4^{\circ} \mathrm{C}$ ), and the pellet resuspended in $1 \mathrm{ml}$ cold buffer solution (50 mM Tris- $\mathrm{HCl}$ ( $\mathrm{pH} 7.5), 0.1 \mathrm{M} \mathrm{NaCl}, 0.5 \mathrm{mM}$ phenylmethylsulphonyl fluoride (PMSF) and $1 \mathrm{mg} / \mathrm{ml}$ iodacetamide). $0.5 \mathrm{ml}$ of the bacterial suspension was then transferred to a FastPrep tube (Anachem, Luton, UK). The tubes were inserted in the FastPrep instrument (Anachem), the speed set to 6 and time to $40 \mathrm{~s}$. Disruption was repeated 10 times to ensure bacteria cells were 


\begin{tabular}{|c|c|c|c|c|}
\hline Strain no. & Genotype & Phenotype & Comment & $\begin{array}{l}\text { Source of } \\
\text { strain }\end{array}$ \\
\hline 57 & S. aureus $8325-4$ & Wild-type strain cured of known prophages & Wild-type & $\begin{array}{l}\text { Laboratory } \\
\text { stock }\end{array}$ \\
\hline PC6911 & $\operatorname{agr} \mathrm{Tc}^{\mathrm{r}}$ & $\begin{array}{l}\text { Deficient in regulatory gene } a g r \text {, so } \\
\text { up-regulates surface proteins }\end{array}$ & $8325-4$ background & $\begin{array}{l}\text { Laboratory } \\
\text { stock }\end{array}$ \\
\hline PC1839 & sarA $\mathrm{Km}^{\mathrm{r}}$ & $\begin{array}{l}\text { Deficient in regulatory gene sar, so } \\
\text { up-regulates surface proteins and } \\
\text { down-regulates proteases }\end{array}$ & $8325-4$ background & $\begin{array}{l}\text { Laboratory } \\
\text { stock }\end{array}$ \\
\hline PC18391 & agr sar $\mathrm{Tc}^{\mathrm{r}} \mathrm{Km}^{\mathrm{r}}$ & $\begin{array}{l}\text { Deficient in regulatory genes agr and sar so } \\
\text { up-regulates surface proteins }\end{array}$ & $8325-4$ background & $\begin{array}{l}\text { Laboratory } \\
\text { stock }\end{array}$ \\
\hline LH01 & agr spa $\mathrm{Em}^{\mathrm{r}} \mathrm{Tc}^{\mathrm{r}}$ & $\begin{array}{l}\text { Deficient in regulatory gene } a g r \text { and } \\
\text { protein A, up-regulates surface proteins } \\
\text { except protein A }\end{array}$ & $8325-4$ background & This study \\
\hline LH02 & sarA spa $\mathrm{Km}^{\mathrm{r}} \mathrm{Tc}^{\mathrm{r}}$ & $\begin{array}{l}\text { Deficient in regulatory gene sar and } \\
\text { protein A, up-regulates surface proteins } \\
\text { except protein A }\end{array}$ & $8325-4$ background & This study \\
\hline LH03 & spa $\mathrm{Tc}^{\mathrm{r}}$ & Protein A deficient & $8325-4$ background & This study \\
\hline LH04 & clfA:: $\operatorname{Tn} 917\left(\mathrm{Em}^{\mathrm{r}}\right)$ & Clumping factor $\mathrm{A}$ deficient & $8325-4$ background & This study \\
\hline LH05 & clfa::Tn917 spa Em$^{\mathrm{r}} \mathrm{Tc}^{\mathrm{r}}$ & Clumping factor $\mathrm{A}$ and protein $\mathrm{A}$ deficient & $8325-4$ background & This study \\
\hline
\end{tabular}

Table 1. List of the S. aureus strains used in this study. $\mathrm{Tc}^{\mathrm{r}}$, tetracycline resistance; $\mathrm{Km}^{\mathrm{r}}$, kanamycin resistance; Ery ${ }^{r}$ erythromycin resistance. PC6911 was used because surface proteins would be over produced; PC1839 because less proteases would be produced and more surface proteins; PC18391 because it is a double mutant deficient in both regulatory genes; LH03 and LH04 are deficient in the proteins of interest and can be used as controls for the antisera specificity; and LH01, LH02 and LH05 to prevent non-specific binding to protein A.

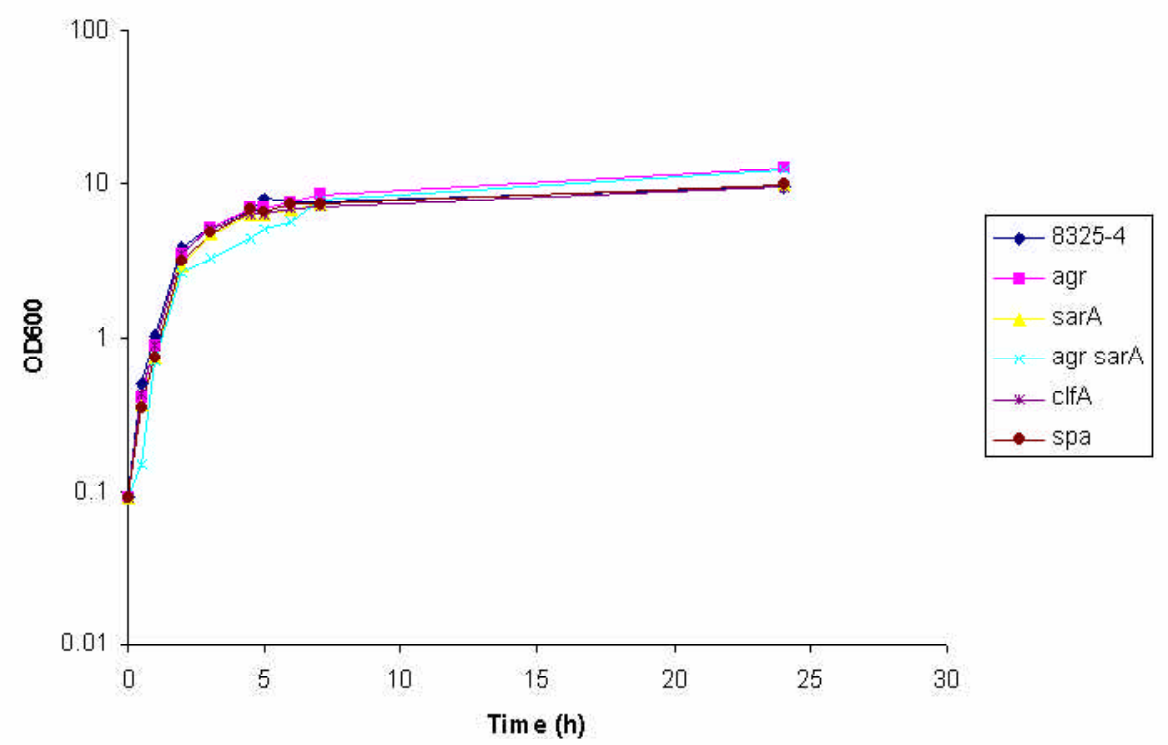

Figure 3. Growth curve of S. aureus 8325-4, PC6911 (agr), PC1839 (sarA), PC18391 (agr sarA), LH03 (spa), and LH04 (clfA) grown at $37^{\circ} \mathrm{C}$ in BHI. 
broken, with cooling on ice in between. The tubes were cooled in ice and breakage of the cells verified by light microscopy. The FastPrep beads were allowed to settle, and the supernatant/suspension removed into a clean tube. $5 \mathrm{ml}$ cold $50 \mathrm{mM}$ Tris- $\mathrm{HCl}$ and $0.1 \mathrm{M} \mathrm{NaCl}$. was added to the suspension, before centrifuging at 2,000 $\mathrm{x} g$ for 10 min at $4{ }^{\circ} \mathrm{C}$. The supernatant was removed and $5 \mathrm{ml}$ cold $50 \mathrm{mM}$ Tris- $\mathrm{HCl}$ and $0.1 \mathrm{M} \mathrm{NaCl}$ added to the pellet. After mixing, the insoluble material was recovered by centrifugation $\left(15,000 \times \mathrm{g}, 10 \mathrm{~min}, 4^{\circ} \mathrm{C}\right)$. The pellets were resuspended in $1 \mathrm{ml}$ cold $50 \mathrm{mM}$ Tris- $\mathrm{HCl}(\mathrm{pH} 7.5)$, and recovered by centrifugation (as above) to give native cell walls.

To isolate proteins ionically bound to the cell wall, cell wall material was resuspended in $200 \mathrm{ml}$ sodium dodecyl sulphate (SDS) sample buffer with 5.6 \% (v/v) 2Mercaptoethanol (BME; added just before used). The suspension was boiled for $3 \mathrm{~min}$, and cooled at room temperature (RT) for $5 \mathrm{~min}$. Insoluble material was removed by centrifugation $(13,000 \mathrm{Xg}, 5 \mathrm{~min}, \mathrm{RT})$ and the supernatant retained for analysis.

The cell wall pellet was resuspended in $1 \mathrm{ml}$ SDS sample buffer with $5.6 \%(\mathrm{v} / \mathrm{v})$ BME. The suspension was boiled for $5 \mathrm{~min}$, and allowed to cool at RT for $5 \mathrm{~min}$. The insoluble material was removed by centrifugation $(13,000$ $\mathrm{x} \mathrm{g}, 5 \mathrm{~min}, \mathrm{RT}$ ) and the pellet resuspended in $5 \mathrm{ml} 2 \%$ (w/v) SDS, $25 \mathrm{mM}$ DL-dithiothreitol (DTT), $50 \mathrm{mM}$ Tris$\mathrm{HCl} \mathrm{pH} \mathrm{7.5,} 1 \mathrm{mM}$ ethylenediamine-tetraacetic acid (EDTA). After boiling and cooling as above, the insoluble material was recovered by centrifugation $(13,000 \mathrm{x}$, $5 \mathrm{~min}, \mathrm{RT})$. The SDS-DTT treatment was repeated and the pellet resuspended in $5 \mathrm{ml} 50 \mathrm{mM}$ Tris- $\mathrm{HCl}, \mathrm{pH} 7.5$. The insoluble material was washed four times by centrifugation and resuspension (as above). The OD of the cell wall suspension at $450 \mathrm{~nm}$ was measured. To $2 \mathrm{OD}_{450}$ units worth of cell wall suspension $1 \mathrm{ml} 5 \mathrm{mg} / \mathrm{ml} \mathrm{lys-}$ ostaphin was added to the suspension and made up to 100 $\mathrm{ml}$ with $50 \mathrm{mM}$ Tris- $\mathrm{HCl}$ ( $\mathrm{pH}$ 7.5). The suspension was incubated by rotating the tubes at $37^{\circ} \mathrm{C}$ for $3 \mathrm{~h}$. Insoluble material was removed by centrifugation $(13000 \mathrm{x} \mathrm{g}, 10$ min, RT). To the supernatant, $25 \mathrm{ml}$ SDS sample buffer (x5 concentrated) and 5.6\% (v/v) BME were added. After boiling ( $3 \mathrm{~min}$ ), and cooling at RT for $5 \mathrm{~min}$ the insoluble material was removed by centrifugation $(13,000 \mathrm{x} \mathrm{g}, 5$ $\min , \mathrm{RT}$ ).

\section{SDS-PAGE and Western blot analysis}

Cell wall associated proteins (prepared as above) were analysed by SDS polyacrylamide-gel electrophoresis (SDS-PAGE; Laemmli, 1970) using $12 \%$ (w/v) or $7.5 \%$ $(\mathrm{w} / \mathrm{v})$ acrylamide gels using a Mini-Protean 3 (BioRad, Hemel Hempstead, UK) gel apparatus for electrophoresis. After gel electrophoresis, gels were either stained with Coomassie blue to visualise protein bands, or soaked in transfer buffer for $30 \mathrm{~min}$. The transfer of proteins to nitrocellulose or polyvinylidene difluoride (PVDF) membrane was carried out in a LKB (Bromma, Sweden) Electroblotter at $0.8 \mathrm{~mA}$ per $\mathrm{cm}^{2}$ of gel for $1 \mathrm{~h}$.

After electrophoresis transfer, the non-specific protein-binding sites on the membrane were blocked by soaking in $6 \%(\mathrm{w} / \mathrm{v})$ skimmed milk powder in Tris buffered saline with Tween 20 (TBST) for $1 \mathrm{~h}$ at room temperature. This solution was replaced by antiserum diluted in $10 \mathrm{ml}$ TBST containing $6 \%(\mathrm{w} / \mathrm{v})$ skimmed milk powder for $1 \mathrm{~h}$. Nitrocellulose membranes were then washed three times for $10 \mathrm{~min}$ in TBST. The membranes were then incubated in the secondary antibody (goat anti rabbit IgG conjugated to alkaline phosphatase; Sigma, Liechtenstein), diluted 30,000 fold in TBST containing $6 \%(\mathrm{w} / \mathrm{v})$ skimmed milk powder for $30 \mathrm{~min}$. The nitrocellulose membranes were washed three times for $10 \mathrm{~min}$ in TBST. The nitrocellulose membranes were equilibrated in AP buffer (1 M Tris- $\mathrm{HCl}(\mathrm{pH} 9.5), \mathrm{NaCl}, \mathrm{MgCl}_{2} .6 \mathrm{H}_{2} \mathrm{O}$ ) for 5 min. The membranes were developed in the dark in 10 $\mathrm{ml}$ AP buffer containing $45 \mu 1$ of 5-bromo-4-chloro-3indolylphosphate toluidine (BCIP) and $10 \mathrm{mg} / \mathrm{ml} \mathrm{nitro-}$ blue tetrazolium chloride (NBT) in dimethyl formamide. Bands appeared within a few minutes to overnight. When the blot had developed to the desired extent, development was stopped by washing in water plus $2 \mathrm{ml}$ each of TrisEDTA (TE) overnight. The membranes were stored dry, and in the dark.

\section{Immunocytochemistry}

$S$. aureus strains were pre-cultured as above and used to inoculate $40 \mathrm{ml}$ pre-warmed BHI (same batch as pre-culture, no antibiotics) in test flasks $(100 \mathrm{ml})$ to a starting $\mathrm{OD}_{600}$ of 0.05 then mixed by shaking as above for $15 \mathrm{~min}$. $1 \mathrm{ml}$ samples of this culture was put on Thermanox ${ }^{\circledR}$ (polyethylene terephthalate; Life Technologies, Basel, Switzerland) discs, and incubated stationary at $37^{\circ} \mathrm{C}$ for $2 \mathrm{~h}, 4 \mathrm{~h}$, and $18 \mathrm{~h}$. All fixation, and rinsing was carried out at $20^{\circ} \mathrm{C}$. All PIPES buffer (Piperazine-1,4-bis-2ethanesulfonic acid; Fluka, Buchs, Switzerland) used was $0.1 \mathrm{M}$ concentration, at $\mathrm{pH} 7.4$ (unless stated otherwise).

The BHI medium was removed and the bacteria were rinsed twice in PIPES buffer for $2 \mathrm{~min}$. The bacteria were fixed in $4 \%(\mathrm{w} / \mathrm{v})$ paraformaldehyde in PIPES buffer for $5 \mathrm{~min}$, and then rinsed $3 \times 2 \mathrm{~min}$ in PIPES buffer. Nonspecific binding sites were blocked with $1 \%(\mathrm{w} / \mathrm{v})$ bovine serum albumin (BSA) and $0.1 \%(\mathrm{w} / \mathrm{v})$ Tween 20 in PIPES buffer for $30 \mathrm{~min}$. The bacteria were then incubated with the one of the antisera listed in Table 2 for $1 \mathrm{~h}$. Bacteria were rinsed 6x $1 \mathrm{~min}$ in PIPES, $1 \% \mathrm{BSA}(\mathrm{w} / \mathrm{v})$ and $0.1 \%(\mathrm{w} / \mathrm{v})$ Tween 20 . More non-specific binding sites were blocked with $5 \%(\mathrm{w} / \mathrm{v})$ goat serum, $1 \%$ BSA $(\mathrm{w} / \mathrm{v})$ and $0.1 \%(\mathrm{w} / \mathrm{v})$ Tween 20 in PIPES buffer for 30 $\mathrm{min}$. The bacteria were secondary labelled with goat antimouse or goat anti-rabbit $5 \mathrm{~nm}$ gold conjugate (British BioCell International, Cardiff, UK), depending on the primary antisera at a dilution of 1:200 in PIPES buffer, 1 $\%(\mathrm{w} / \mathrm{v})$ BSA and $0.1 \%(\mathrm{w} / \mathrm{v})$ Tween 20 for $1 \mathrm{~h}$. The samples were then fixed with $2.5 \%$ glutaraldehyde in PIPES for 5 min., then rinsed 3x $2 \mathrm{~min}$ in PIPES buffer before being silver enhanced for $3 \mathrm{~min}$ followed by $4 \times 2 \mathrm{~min}$ rinses in ultra high purity distilled water. Samples were post-fixated using $1 \%(\mathrm{w} / \mathrm{v}) \mathrm{OsO}_{4}$ in PIPES pH 6.8 was for $1 \mathrm{~h}$. The bacteria were rinsed $3 \times 2$ min in PIPES buffer at $\mathrm{pH} 6.8$, before being dehydrated and mounted poststaining with $1 \% \mathrm{OsO}_{4}$ in PIPES ( $\mathrm{pH} \mathrm{6.8)} \mathrm{for} 1 \mathrm{~h}$. The fixed bacteria were taken through an ethanol $(\mathrm{v} / \mathrm{v})$ series $(50 \%, 70 \%, 96 \%, 100 \%)$ for $5 \mathrm{~min}$ each. The ethanol 


\begin{tabular}{|l|l|l|}
\hline Antisera & Dilution & Source \\
\hline Monoclonal Anti-protein A (Spa), mouse ascites fluid & $1 / 500$ & Sigma \\
\hline Anti-ClfA, rabbit ascites fluid & $1 / 500$ & TJ Foster, Dublin \\
\hline
\end{tabular}

Table 2 List of antisera used in immunolabelling experiments.

was then substituted using 1:3,1:1 and 3:1 fluorisol: ethanol for $5 \mathrm{~min}$ each, then $100 \%$ (v/v) fluorisol for $5 \mathrm{~min}$. Following this the samples were critically point dried in a POLARON E3000 critical point drier (AGAR Scientific, Stansted, UK), The samples were mounted onto stubs and coated with $8 \mathrm{~nm} \mathrm{Au} / \mathrm{Pd}$ (or with $15 \mathrm{~nm}$ carbon for immunocytochemistry) in a Baltec MED 020 unit (Baltec, Balzers, Liechtenstein). Specimens were examined with either a Hitachi S-4100 or S-4700 Field Emission Scanning Electron Microscope (FESEM; Hitachi Scientific, Düsseldorf, Germany) fitted with a Autrata yttrium aluminium garnet (YAG) backscattered electron (BSE) detector, and operated in secondary electron (SE) and BSE detection modes. The microscopes were operated at accelerating voltages $5 \mathrm{kV}$, with a high emission current of $40 \mu \mathrm{A}$, and a working distance of $10 \mathrm{~mm}$ (Richards and ap Gwynn, 1995). Digital images were taken using the Quartz PCI image acquisition system (Quartz Imaging, Vancouver, Canada).

A control for immunolabelling was also carried out by omitting the primary antibody from the labelling method, leaving the sample in $1 \%(\mathrm{w} / \mathrm{v}) \mathrm{BSA}$ and $0.1 \%(\mathrm{w} / \mathrm{v})$ Tween 20 in PIPES buffer for $1 \mathrm{~h}$ whilst the other samples were labelled with one of the antisera listed in Table 2. The method was the same after this step.

\section{Results}

\section{SDS-PAGE and Western blot analysis}

In order to begin to identify proteins observed on the SDSPAGE gels, Western blot analysis was carried out using specific anti-sera against the known proteins, protein A, and clumping factor A. S. aureus 8325-4, PC6911 (agr), PC1839 (sarA) PC18391 (agr sarA), LH03 (spa) and LH04 ( $c l f A$ ) were harvested and covalently bound proteins extracted. Samples were separated on $12 \%(\mathrm{w} / \mathrm{v})$ SDS-PAGE and blotted on nitrocellulose membrane.

Anti-protein A sera was used to analyse the distribution of protein A , a $42-\mathrm{kDa}$ protein in the cell wall of various strains during growth. On the $12 \%(\mathrm{w} / \mathrm{v})$ SDSPAGE gels (Fig. 4i-iii), the protein A band was not obvious in comparison to the $24-\mathrm{kDa}$ lysostaphin band, clearly present in all lanes. Western blot of 8325-4 sample revealed three cross reactive bands, of around 36-, 40- and 45-kDa (Fig. 4ii). Strain LHO3 (spa) revealed two cross reactive bands of 36- and 40-kDa (Fig. 4ii). Thus the specific reactivity is associated with the $45-\mathrm{kDa}$ protein, that is missing in LH03 (spa). In 8325-4 protein A shows a growth phase dependence only being present during exponential growth. However, in PC6911 (agr) a greater level of protein $\mathrm{A}$ is present throughout growth (Figure 4ii). In PC1839 (sarA) and PC18391 (agr sarA), several bands were observed showing cross-reactivity to protein A (Fig. 4iii). This is most likely due to proteolytic digestion of protein A by SarA repressed proteases.

Anti-ClfA sera was used to analyse the presence of clumping factor A during growth. ClfA has previously been shown to be covalently bound to the peptidoglycan (Hawiger et al., 1982; McDevitt et al., 1994). No obvious differences were seen on the $12 \%(\mathrm{w} / \mathrm{v})$ SDS-PAGE gels (Fig. 5i) between the different strains and the clfA mutant. In 8325-4 several bands were observed on the Western blot which cross reacted with the ClfA antisera (Fig. 5ii). At $2 \mathrm{~h}$, a band of around $45-\mathrm{kDa}$ was seen. Later during growth several bands of between 36-66-kDa were apparent. In PC6911 (agr) only a single band of around 45$\mathrm{kDa}$ was apparent throughout growth. All cross reactive material observed in 8325-4 and PC6911 is ClfA, as LH04 $(\mathrm{clf} A)$ showed no reactivity at all. In strains containing the sarA mutation (Fig. 5iii), bands of around 48-, 66and $>66-\mathrm{kDa}$ were seen. At $4 \mathrm{~h}$ and $18 \mathrm{~h}$ all reactive banding has disappeared from PC1839 ( $\operatorname{sar} A)$, whereas PC18391 (agr sarA) had the same bands present at $2 \mathrm{~h}$ as PC1839 (sarA).

Full size ClfA has been reported to be a protein of 92$\mathrm{kDa}$ (McDevitt et al., 1994). Hence, the same covalently bound protein samples were separated on $6 \%$ SDS-PAGE gels. However, the Western blots showed no extra bands in any lanes (results not shown).

\section{Immunocytochemistry}

Immunocytochemistry was used to analyse the surface location of $S$. aureus protein A and clumping factor A. Monoclonal anti-protein A sera (SPA-27, Sigma) was used to study the location of protein A on the cell wall of various strains of $S$. aureus during growth. At $2 \mathrm{~h}$, a variation in the amount of immunogold labelling was observed between the different strains (Fig. 6i-vi). S. aureus 8325-4 appeared to have less label than the mutants PC6911 (agr), PC1839 (sar) and PC18391 (agr sar). No immunogold labelling was observed on LH03 (spa) bacteria (Figure $6 \mathrm{v}$ ), and the control bacteria which were not labelled with anti-Spa sera had no labelling on their surfaces or background labelling (Figure 6vi). Background labelling was observed in most cases, including LH03, around the spa mutant bacteria. 

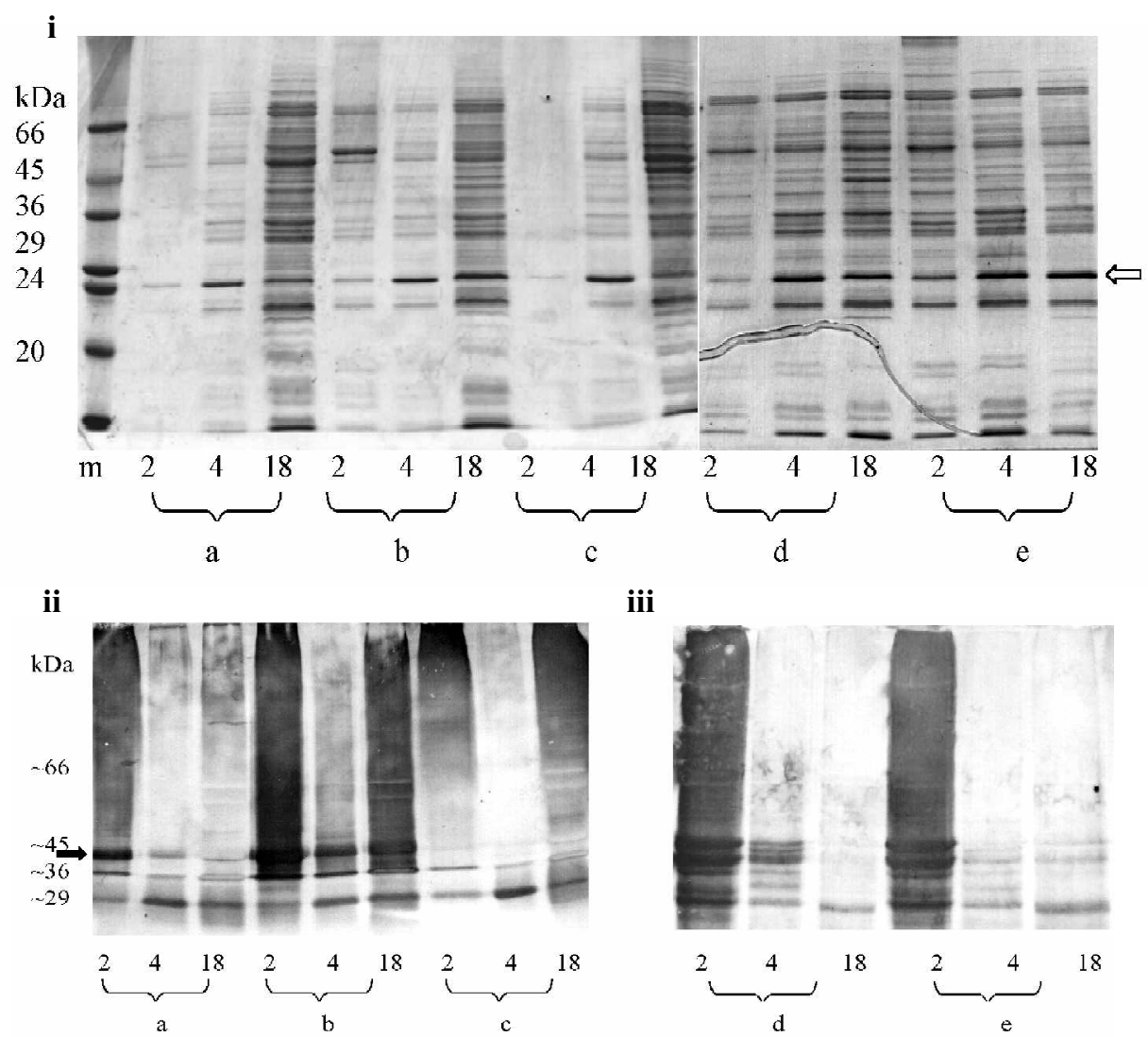

iii

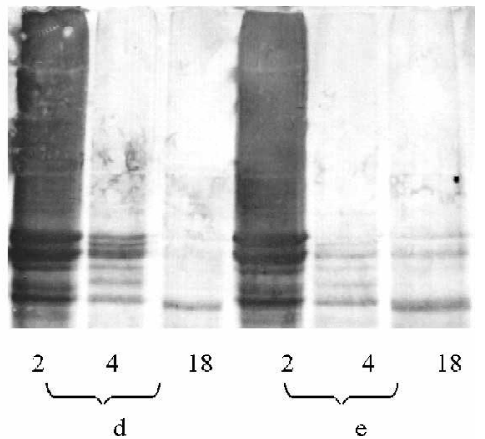

Figure 4. $12 \%(\mathrm{w} / \mathrm{v})$ SDSPAGE and Western blot analysis of proteins covalently bound to the cell wall. Samples were harvested after 2, 4, and $18 \mathrm{~h}$ growth (as indicated). Proteins covalently bound to the peptidoglycan were prepared as described, and separated by $12 \%(\mathrm{w} / \mathrm{v})$ SDSPAGE before blotting onto nitrocellulose membranes, and anti-Spa sera was used on the Western blots. $0.25 \mathrm{OD}_{600}$ units per lane. $\mathrm{m}=$ Dalton VII standard marker of sizes indicated; Gel (i) is the $12 \%$ (w/ v) SDS-PAGE and contains a) S. aureus 8325-4; b) PC6911 $(a g r)$; c) LH03 (spa); d) PC1839 (sarA) and e) PC18391 (agr sarA). Gel (ii) and (iii) are Western blots of gel (i). White arrow points to the lysostaphin band, and the black arrow shows presence of protein A on the membrane.

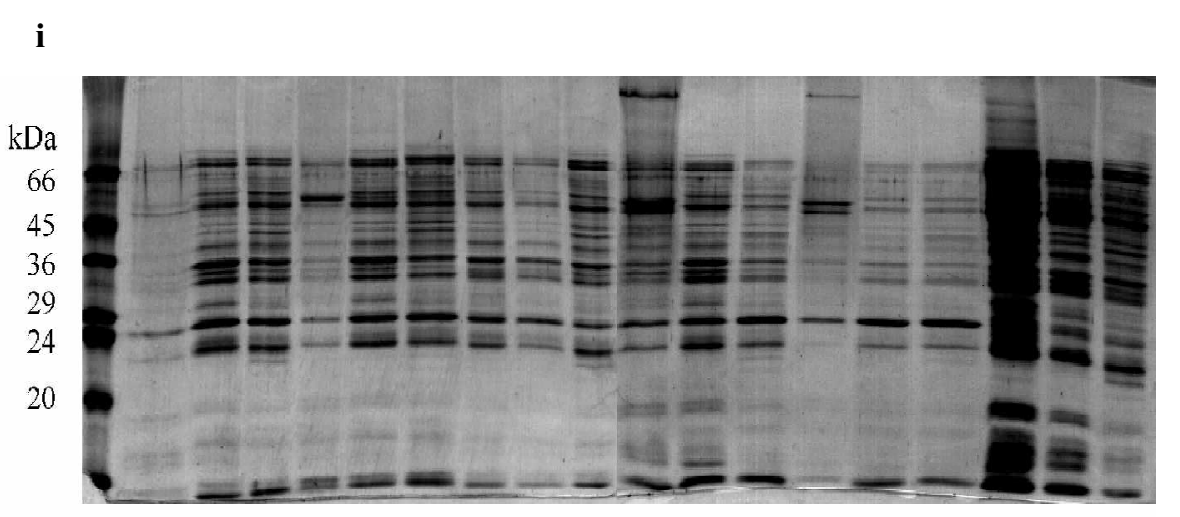

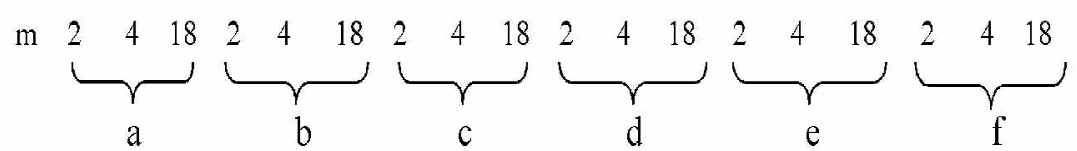

ii

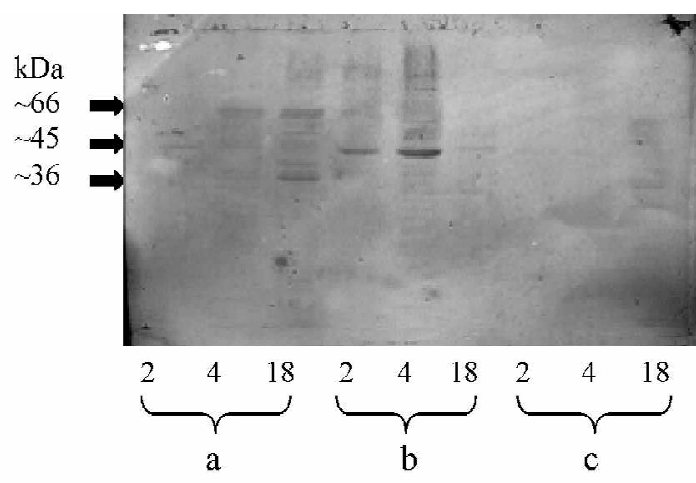

iii

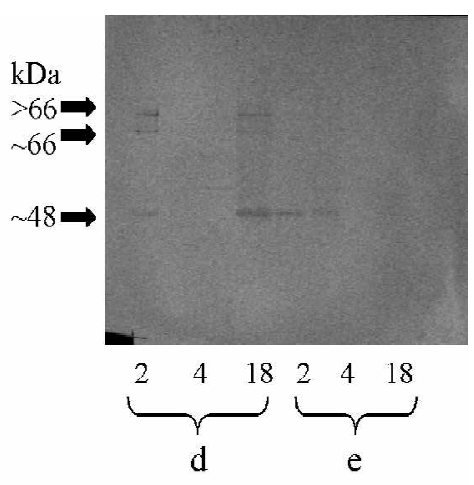

Figure 5. $12 \%(\mathrm{w} / \mathrm{v})$ SDSPAGE and Western blot analysis of proteins covalently bound to the cell wall. Samples were harvested from various strains after 2,4 , and $18 \mathrm{~h}$, and the covalently bound proteins extracted by FastPrep, digested with lysostaphin, and boiled for 3min in SDS-sample buffer before separating on $12 \%$ SDS-PAGE gels and blotting onto nitrocellulose membranes. Anti-ClfA sera was used on the Western blots as described in section 2.9.2. $\mathrm{m}=$ Dalton VII standard marker of sizes shown; a) $S$. aureus 8325-4, b) PC6911 $(a g r), \mathrm{c}) \mathrm{LH} 04($ clf $A), \mathrm{d})$ PC1839 (sarA), and e) PC18391 (agr sarA). Black arrows show presence of ClfA. 
The amount of immunogold labelling after $4 \mathrm{~h}$, varied depending on the strain (Fig. 7i-vi). Immunogold labelled protein A was seen on the surfaces of 8325-4 (Fig. 7i), PC6911 (agr) (Fig. 7ii), and PC18391 (agr sar) (Fig. 7iv), however immunogold labelling was only observed on the surfaces of some PC1839 (sarA) (Fig. 7iii). LH03 (spa) and the controls showed no immunogold labelling (Fig. $7 \mathrm{v}$ and $7 \mathrm{vi}$ ). Background labelling was less in $4 \mathrm{~h}$ samples than in $2 \mathrm{~h}$ samples.

Eighteen hours after culturing, immunogold labelling of protein A was observed on most strains, to varying degrees (Fig. 8i-vi). The amount of immunogold label appeared to be greater on PC6911 (agr) than at 2 and 4h (Fig. 8ii). The immunogold labelling observed on 83254, PC1839 (sarA), and PC18391 (agr sarA) were similar in amount to the samples labelled after $2 \mathrm{~h}$ (Fig. 6). Background labelling was also minimal compared to samples at $2 \mathrm{~h}$.

No pattern was observed in the way the bacteria had been immunogold labelled over time. The bacteria surface topography observed using conventional fixation methods were not seen so clearly following immunocytochemistry and carbon coating. Division lines were observed in some samples.

S. aureus 8325-4, LH01 (agr spa), LH02 (sarA spa), LH03 (spa) and LH06 ( clfA spa) were cultured, harvested and immunogold labelled as described previously. The double mutants (LH01, LH02 and LH06) were constructed by transducing spa into PC6911 (agr), PC1839 (sarA) and LH04 (clfA) backgrounds. This would prevent nonspecific binding of IgG to Spa.

Two hours after culturing, very little variation was observed in the amount of immunogold labelling on the surface of the different strains (Fig. 9i-vi). The immunogold labelling was due to the labelling of ClfA and not Spa because LH03 (spa) also had labelling on its surface (Fig. 9iv). Background labelling was present on the samples, including on the LH06 sample (clfA spa) (Fig. 9v), which had no labelling on the cell surface, confirming the labelling observed on the other samples is ClfA. No immunogold labelling was seen on the bacterial surface or in the background of the control (Fig. 9vi).

Very little immunogold labelling was seen on $4 \mathrm{~h}$ samples compared to $2 \mathrm{~h}$ (Fig. 10i-vi). No immunogold labelling was seen on 8325-4 (Fig. 10i) or LH03 (spa) (Fig. 10iv). LH01 (agr spa) had immunogold labelling on the surface (Fig. 10ii), whilst much more labelling was observed on LH02 (sarA spa) (Fig. 10iii). The two control samples, LH06 (clfA spa) which do not express ClfA and the sample not labelled with anti-ClfA had no gold on their surfaces (Fig. 10v and 10vi). No background labelling was observed on any of the samples.

At 18h, immunogold labelling was observed (Fig. 11ivi). The amount seen on the surface of 8325-4, LH01 ( $a g r$ spa) and LH03 (spa) was similar (Fig. 11i, 11 ii and 11iv), whilst LH02 (sarA spa) had little immunogold labelling to be seen on the surface. No immunogold labelling was seen on LH06 (clfA spa) (Fig. 11v) or on the control samples (Fig. 11vi). Very little background labelling was observed on the samples.
No distinct immunogold labelling pattern was seen on any of the samples, even at different times during growth.

\section{Discussion}

This study has described experiments to develop a reliable method for extracting proteins from $S$. aureus cell walls, with the intention of identifying ionic and covalently bound proteins. Previous studies have solubilised cell wall associated proteins directly using different peptidoglycan hydrolase or chemical extraction (Sugai et al., 1990; Foster, 1992). Over the years, many have obtained cell wall extracts by physically disrupting the cell wall (Ames and Nikaido, 1976; Foster, 1992; Navarre et al., 1998). In this study the physical disruption of the cells gave a convenient method for purification of native cell walls. Washing with low salt buffer released non specifically associated proteins (Foster, 1993). Extraction of the native cell walls with SDS efficiently removed ionically bound proteins (Figure 3.1. lane 9). Several proteins ionically bound to the cell walls of $S$. aureus have previously been identified. These include the multiple form of the major autolysin, Atl (Foster, 1995). Once the ionically bound proteins had been removed, the covalently bound proteins can be solubilised by digestion of the native cell wall with a peptidoglycan hydrolase. The advantage of disrupting the cell walls prior to digestion with a peptidoglycan hydrolase is that proteins not specifically associated with the cell wall have already been removed.

Several surface proteins have been found to be covalently bound to the insoluble cell wall peptidoglycan in $S$. aureus by a mechanism requiring a $\mathrm{COOH}$-terminal sorting signal with a conserved LP $X$ TG motif (Navarre and Schneewind, 1999). The linkage occurs via a direct bond between the proteins and the glycine residues of the peptidoglycan (Schneewind et al., 1995). It has been proposed that surface proteins of $S$. aureus are linked to the cell wall by sortase, an enzyme that cleaves the polypeptide between the threonine and the glycine of the LPXTG motif, and captures cleaved polypeptides as thioester enzyme intermediates (Ton-That et al., 1999). Such cleavage appears to catalyse the formation of an amide between the carboxyl-group of threonine and the amino-group of peptidoglycan cross-bridges (Mazmanian et al., 2001).

In $S$. aureus, the synthesis of surface proteins occurs in early growth and is down-regulated in post-exponential and stationary growth (Kornblum et al., 1990; Projan and Novick, 1997). This was shown by Western blot analysis of covalently bound proteins using anti-Spa and antiClfA sera. In 8325-4, protein A was shown to be growth phase dependent and regulated by the regulatory locus agr, since PC6911, the agr mutant had protein A present throughout growth (Figure 4ii). It is known that the $a g r$ locus down-regulates the production of surface proteins (Foster and McDevitt, 1994; Chan and Foster, 1998), hence an agr mutation would result in increased production of surface proteins. The Spa cross-reactive bands observed in PC1839 (sar) and PC18391 (agr sar) were the result of the proteolytic digestion of protein A by 


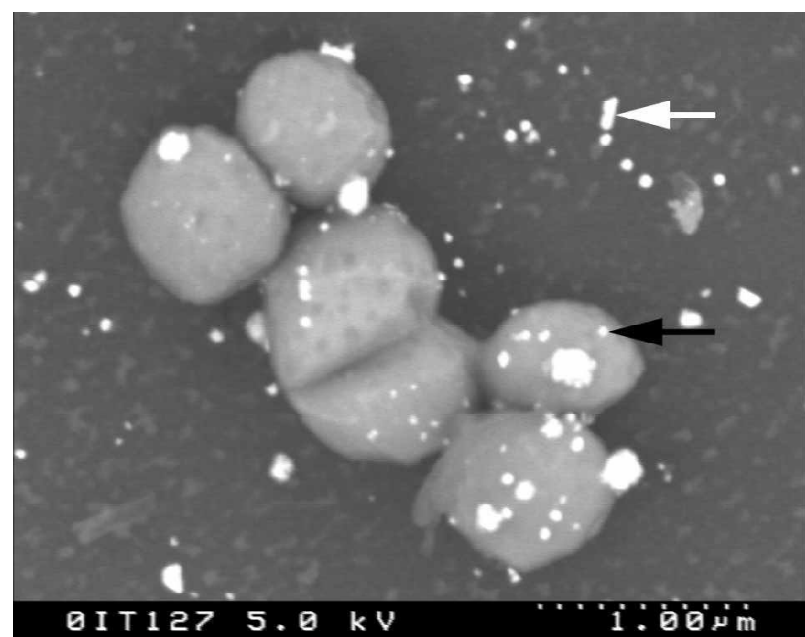

i

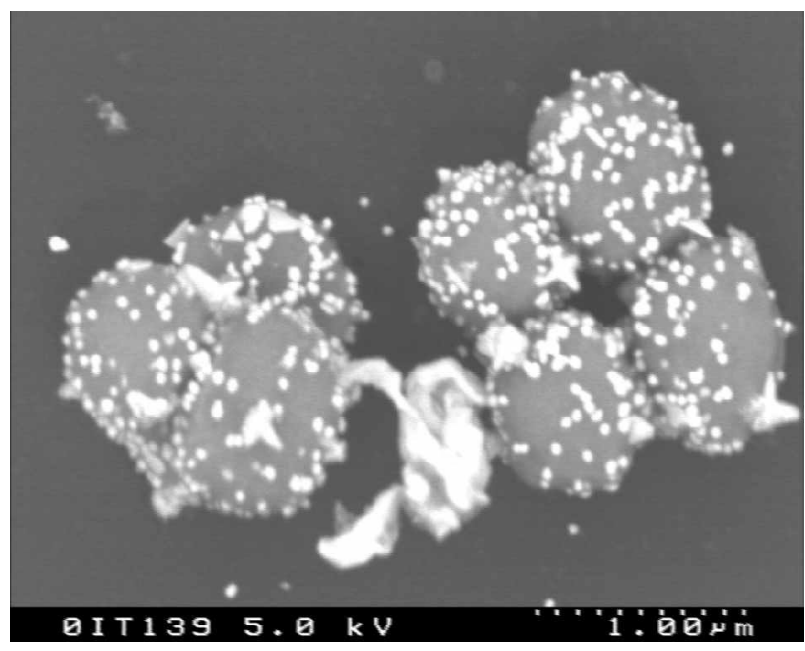

iii

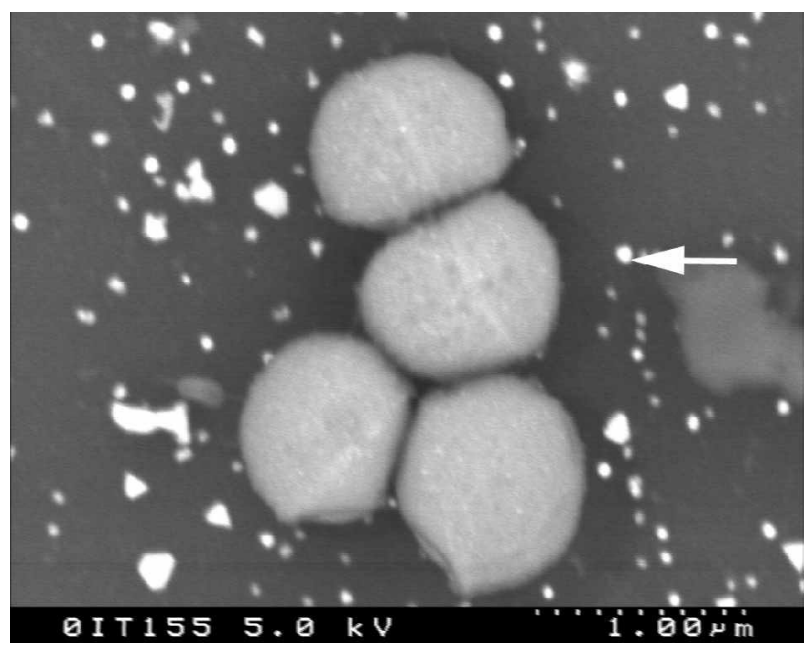

v

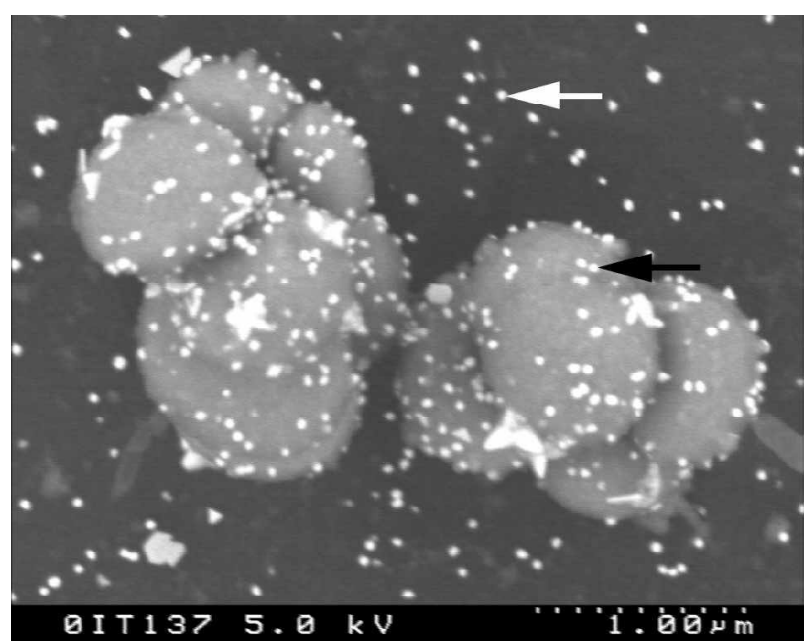

ii

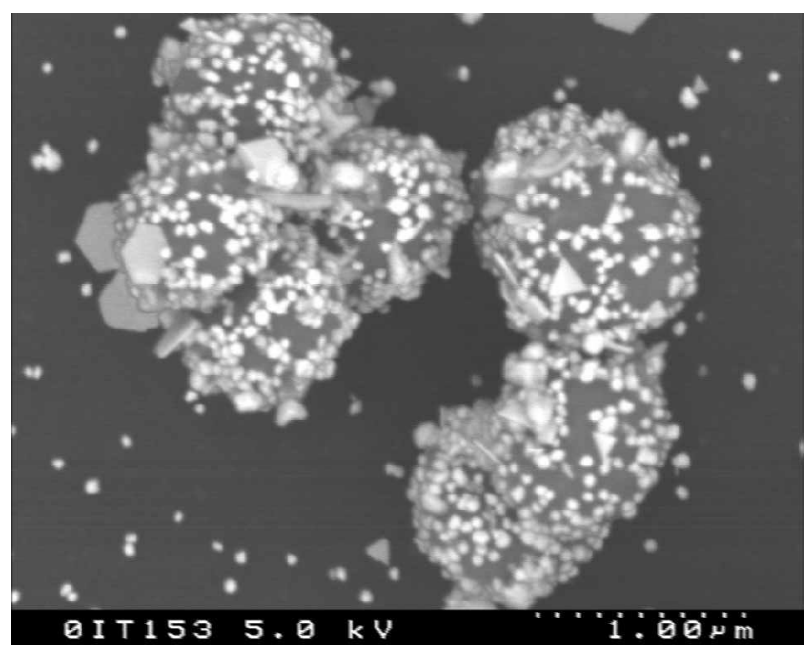

iv

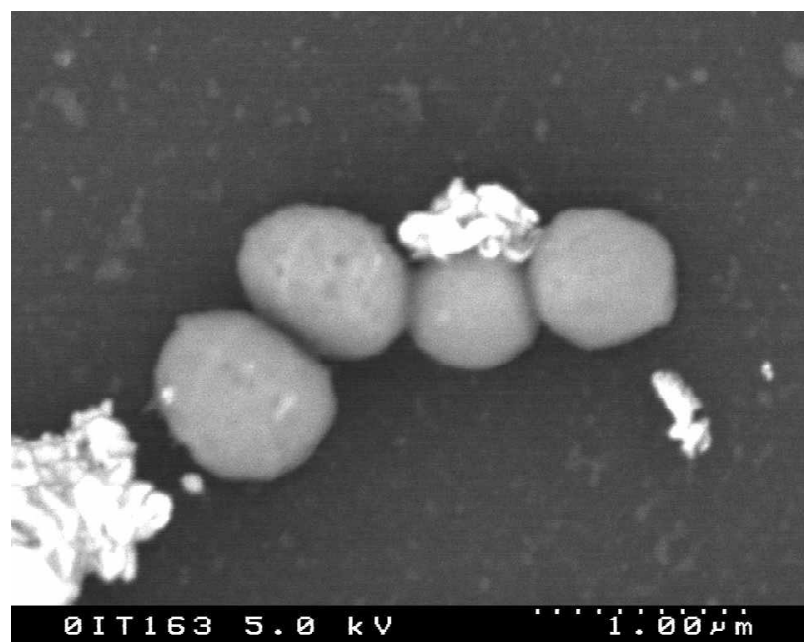

vi

Figure 6. BSE images of $S$. aureus strains grown on Thermanox for $2 \mathrm{~h}$, then immunogold labelled with anti-spa, and imaged using Hitachi S-4100 FESEM with accelerating voltage of $5 \mathrm{kV}$, and $40 \mu \mathrm{A}$ emission current. i) $S$. aureus 8325-4; ii) PC6911 (agr); iii) PC1839 (sarA); iv) PC18391 (agr sarA); v) LH03 (spa); and vi) control, PC6911 (agr), no primary antisera. Immunogold label seen on most bacteria (black arrows) with the exception of LH03 and the control sample. Labelling is not uniform and gold label not round in shape. White arrows indicate presence of background labelling. 


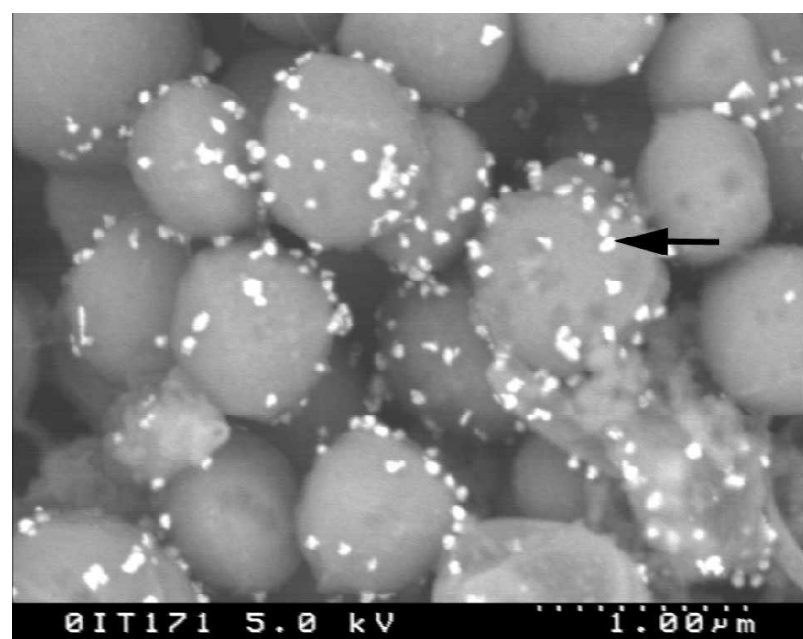

i

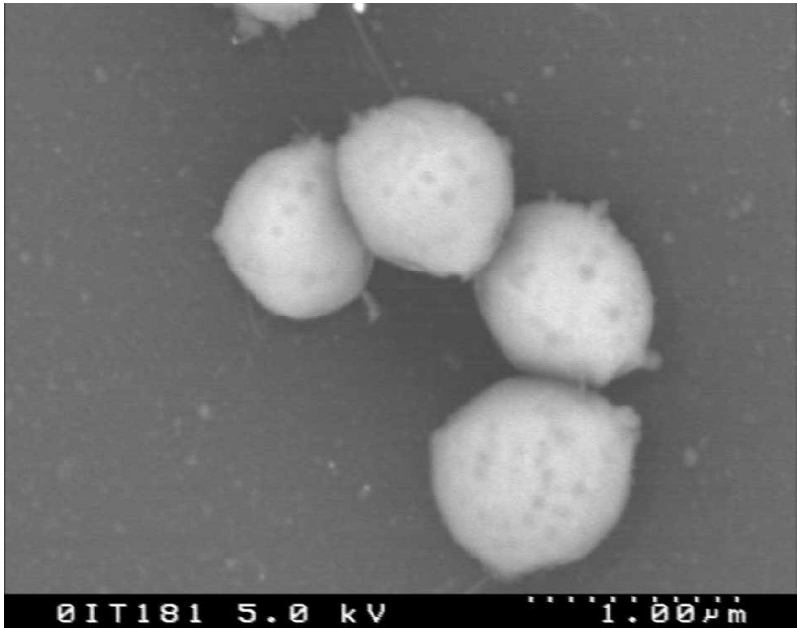

iii

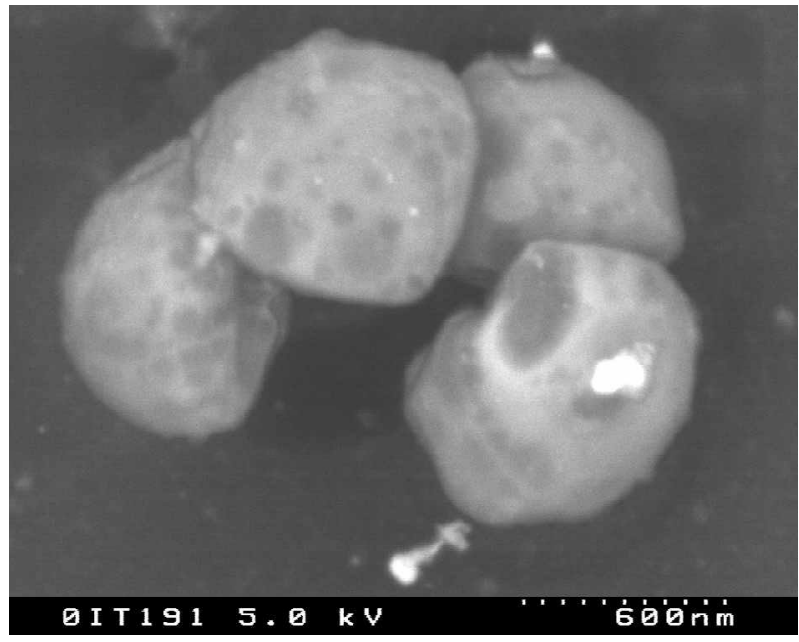

v

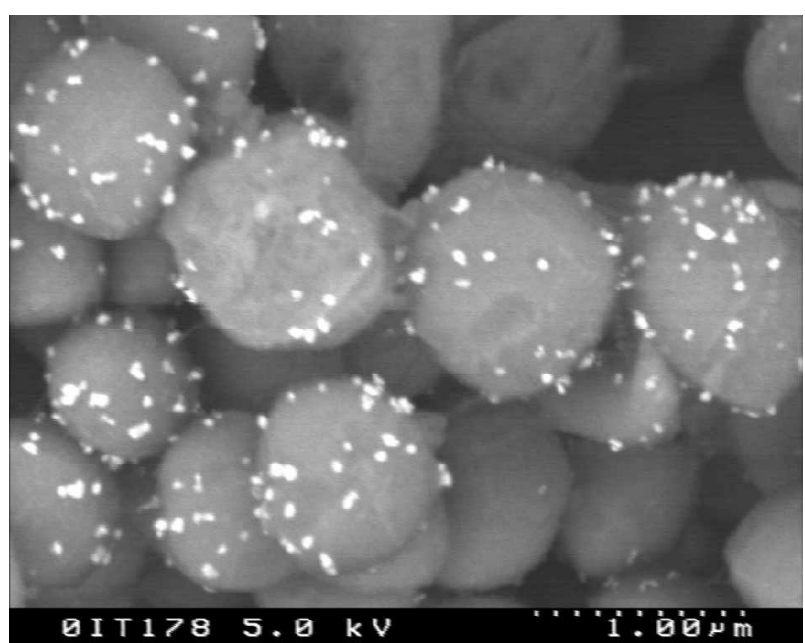

ii

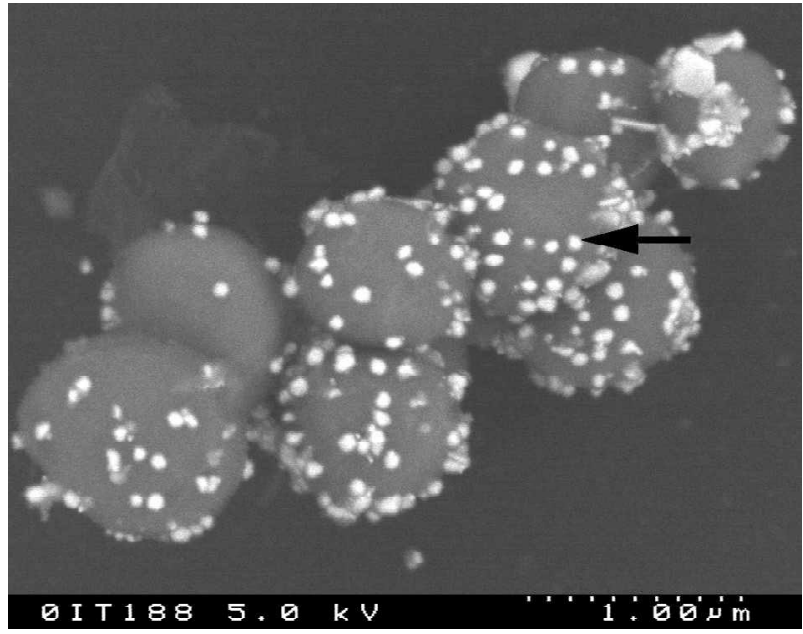

iv

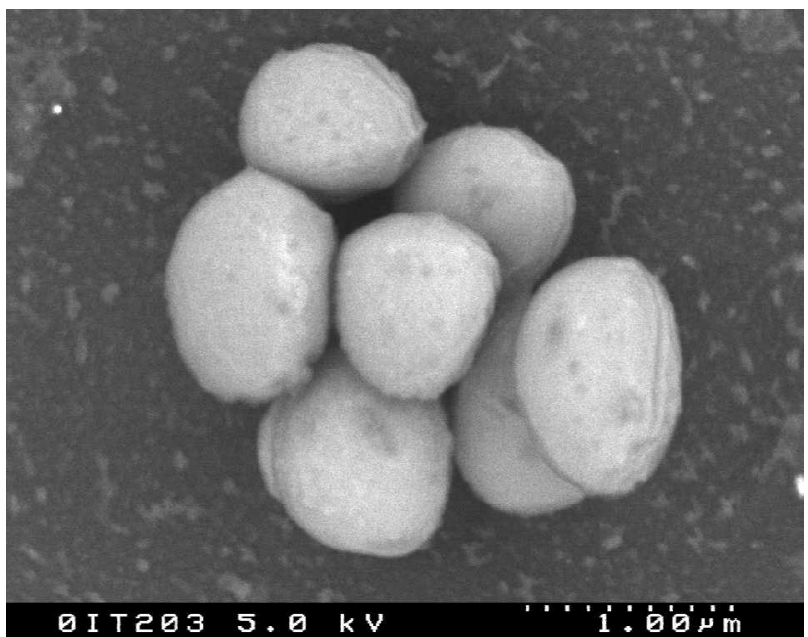

vi

Figure 7. BSE images of $S$. aureus strains grown on Thermanox for 4 h, then immunogold labelled with anti-spa, and imaged using Hitachi S-4100 FESEM with accelerating voltage of $5 \mathrm{kV}$, and $40 \mu \mathrm{A}$ emission current. i) $S$. aureus 8325-4; ii) PC6911 (agr); iii) PC1839 (sarA); iv) PC18391 (agr sarA); v) LH03 (spa); and vi) control, $8325-4$, no primary antisera. Black arrows indicate presence of immunogold labelling on the surface of the bacteria. 


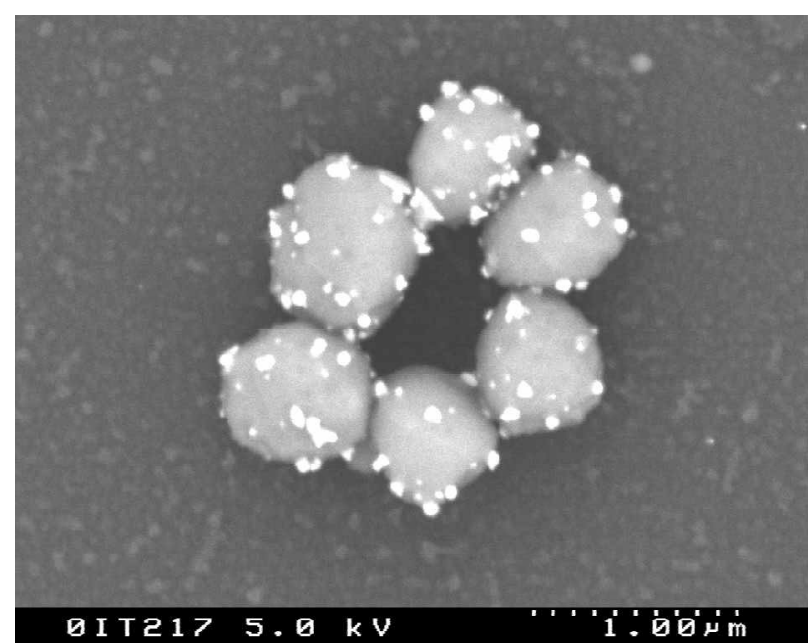

i

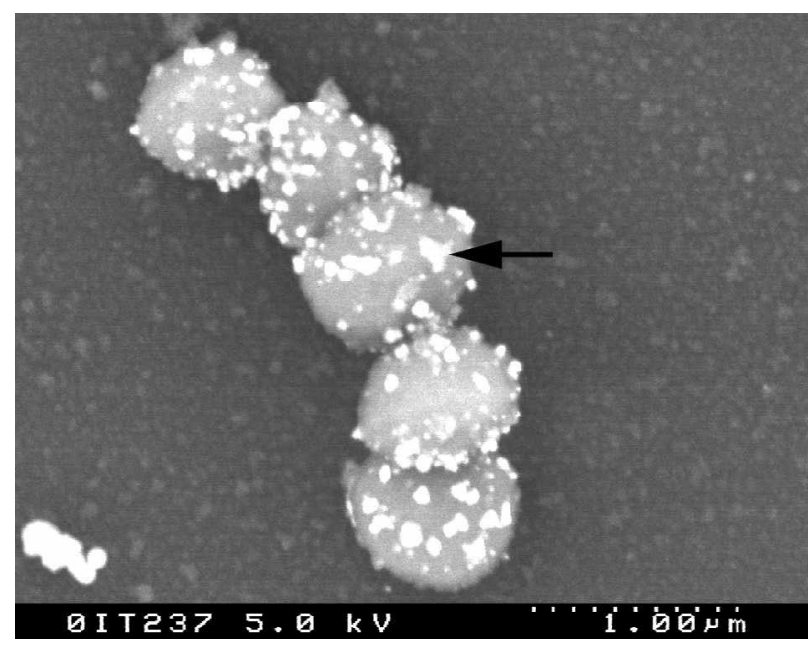

iii

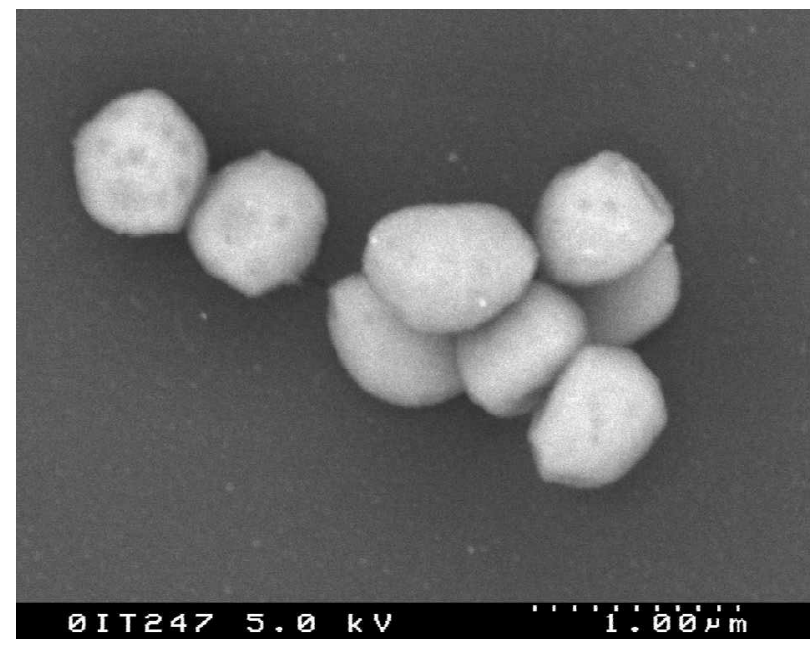

$\mathbf{v}$

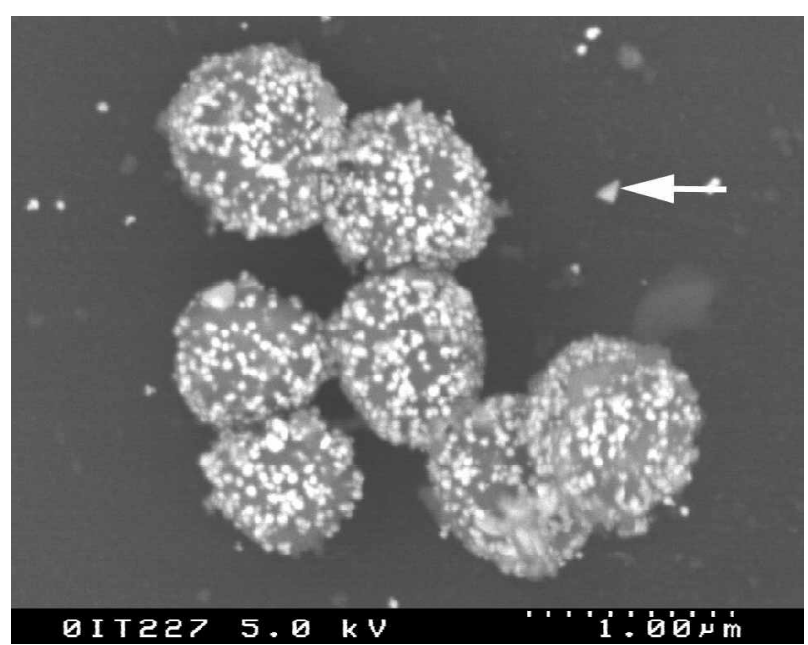

ii

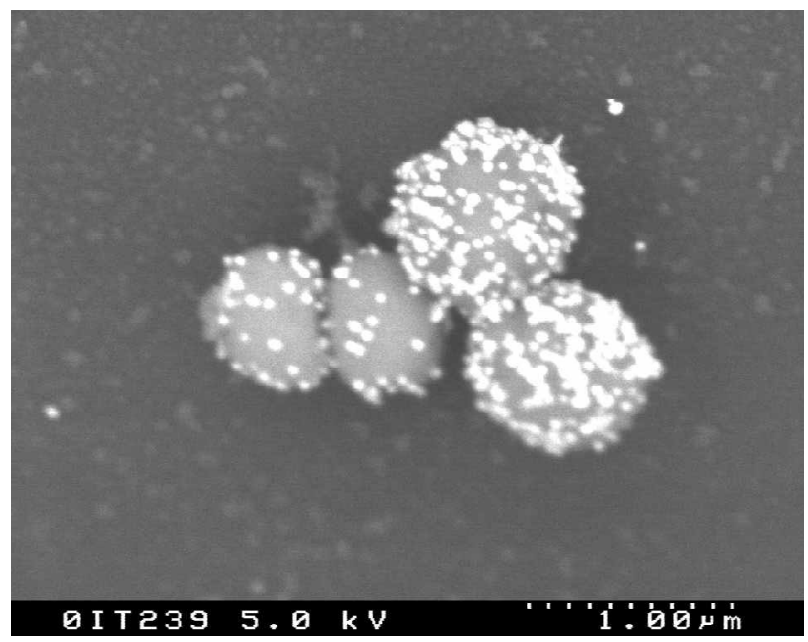

iv

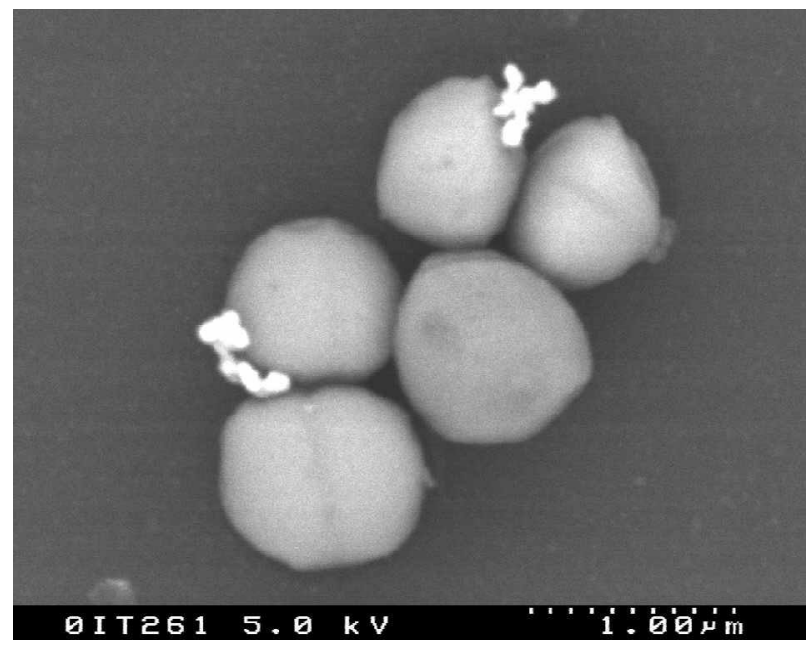

vi

Figure 8. BSE images of $S$. aureus strains grown on Thermanox for $18 \mathrm{~h}$, then immunogold labelled with antispa, and imaged using Hitachi S-4100 FESEM with accelerating voltage of $5 \mathrm{kV}$, and $40 \mu \mathrm{A}$ emission current. i) S. aureus 8325-4; ii) PC6911 (agr); iii) PC1839 (sarA); iv) PC18391 (agr sarA); v) LH03 (spa); and vi) control, PC1839 (sarA), no primary antisera. Black arrows indicates presence of immunogold labelling on the surface of the bacteria, and white arrow indicates background labelling. 


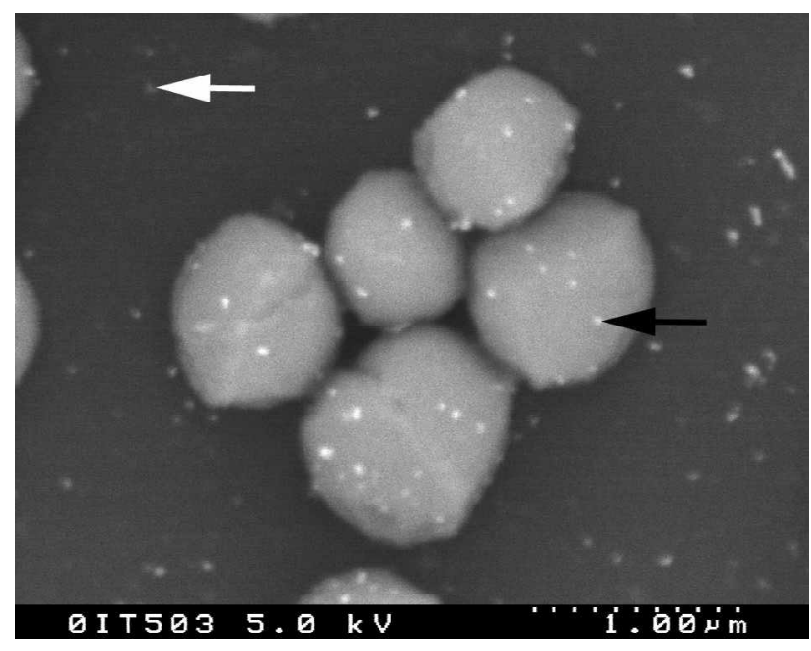

i

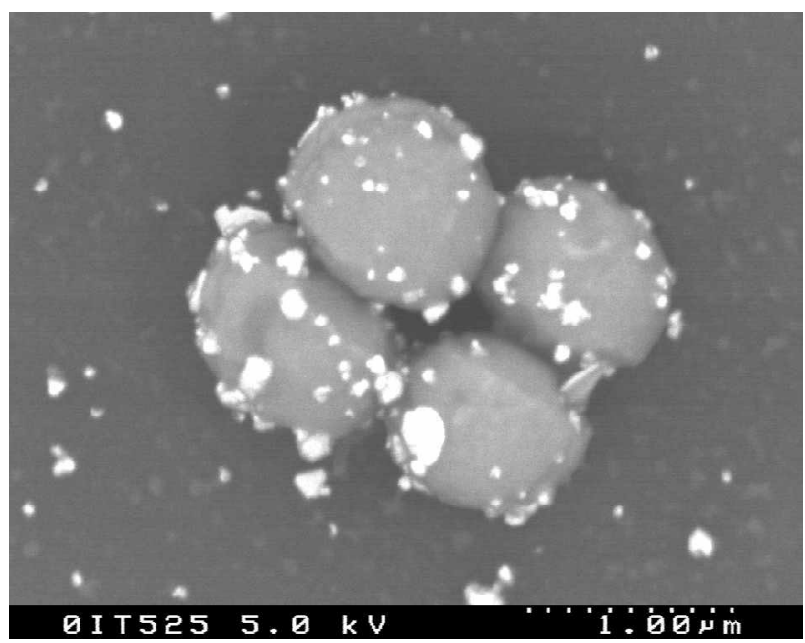

iii

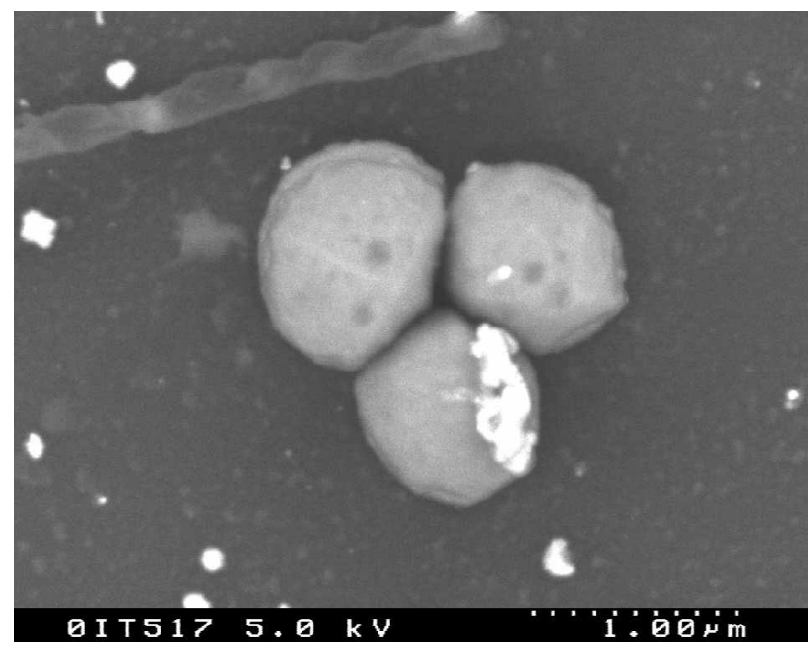

$\mathbf{v}$

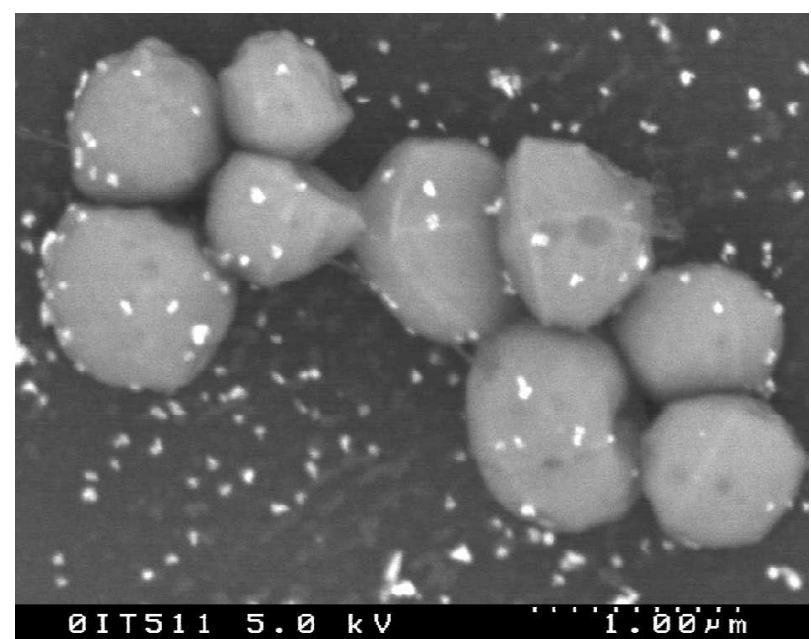

ii

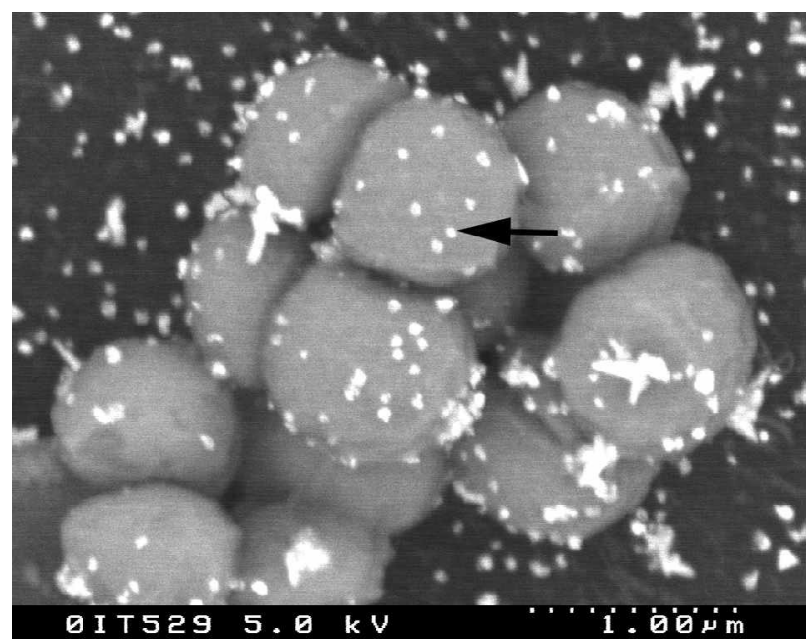

iv

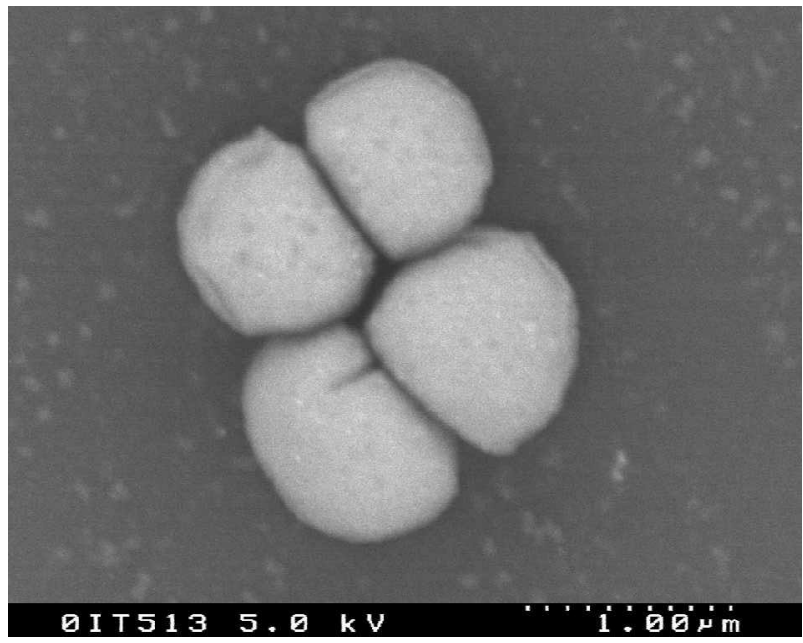

vi

Figure 9. BSE images of $S$. aureus strains grown on Thermanox for $2 \mathrm{~h}$, then immunogold labelled with antiClfA, and imaged using Hitachi S-4100 FESEM with accelerating voltage of $5 \mathrm{kV}$, and $40 \mu \mathrm{A}$ emission current. i) S. aureus 8325-4; ii) LH01 (agr spa); iii) LH02 (sarA spa); iv) LH03 (spa); v) LH06 (clfA spa); and vi) control, LH01 (agr spa), no primary antisera. Black arrows indicate presence of immunogold labelling on the surface of the bacteria. White arrow indicates presence of background labelling. 


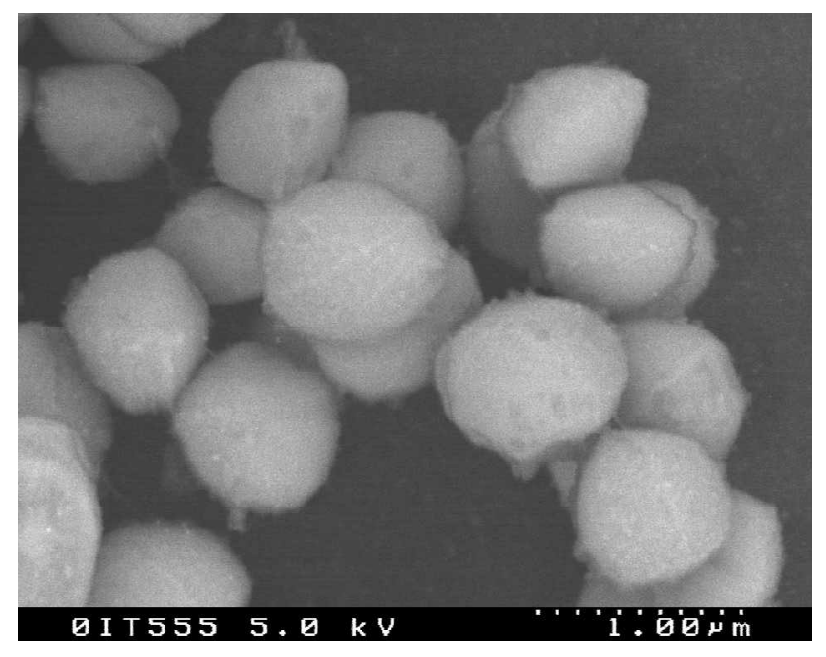

i

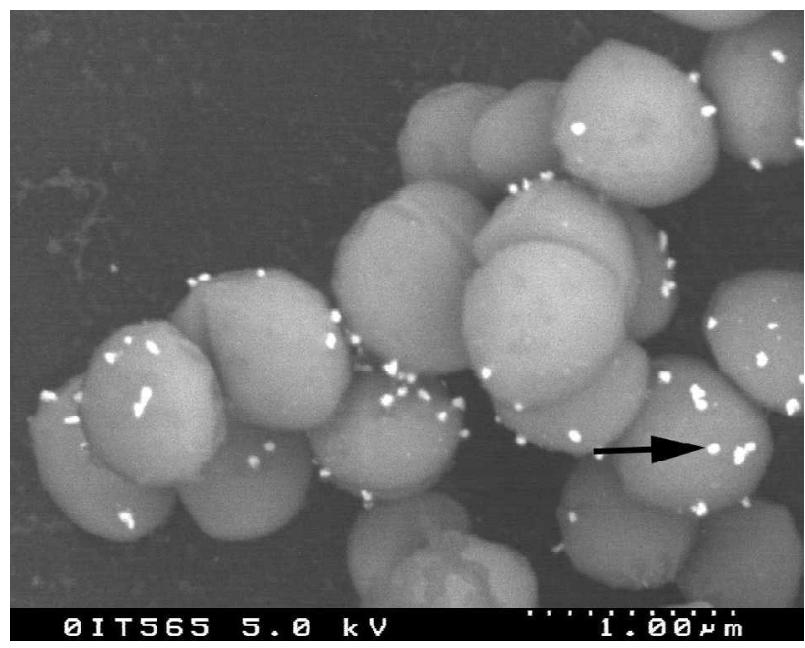

iii

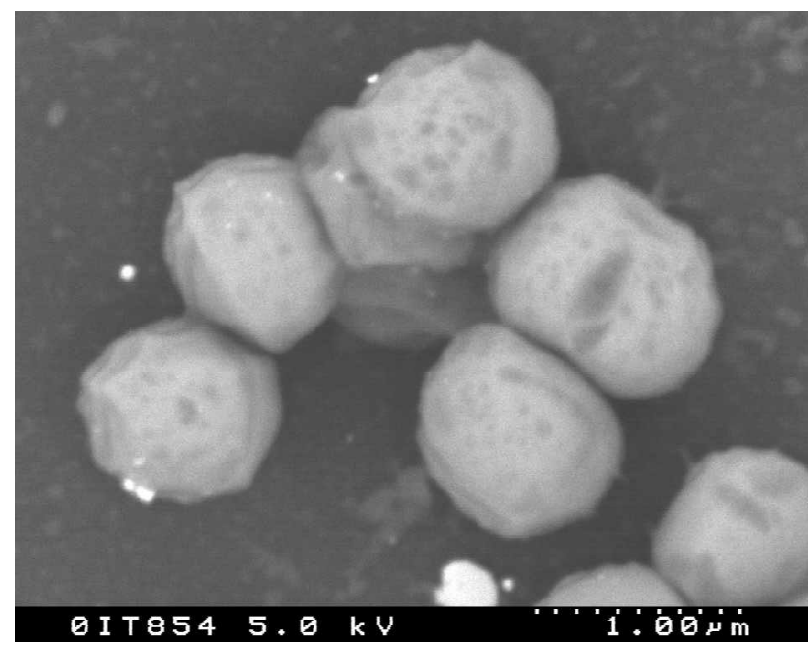

$\mathbf{V}$

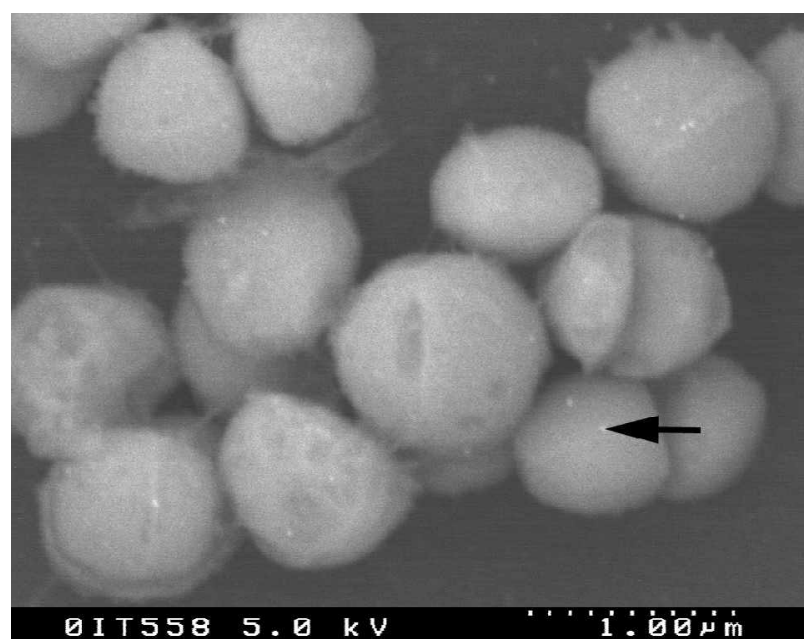

ii

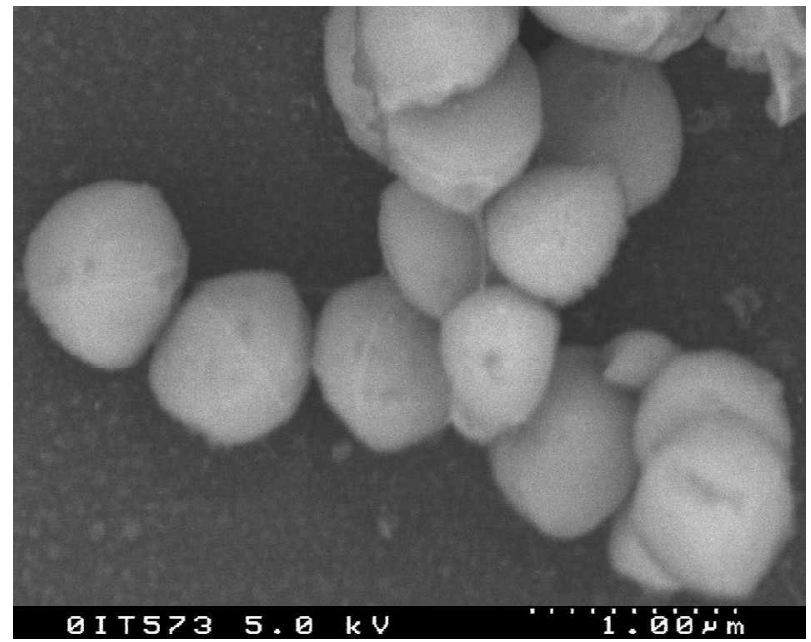

iv

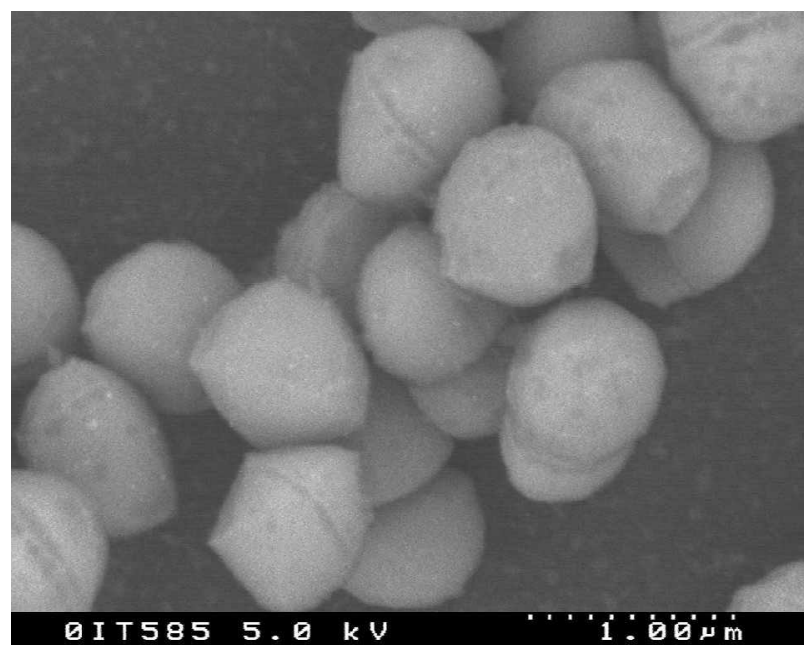

vi

Figure 10. BSE images of $S$. aureus strains grown on Thermanox for 4 h, then immunogold labelled with antiClfA, and imaged using Hitachi S-4100 FESEM with accelerating voltage of $5 \mathrm{kV}$, and $40 \mu \mathrm{A}$ emission current. i) S. aureus 8325-4; ii) LH01 (agr spa); iii) LH02 (sarA spa); iv) LH03 (spa); v) LH06 (clfA spa); and vi) control, LH01 (agr spa), no primary antisera. Black arrows indicate presence of immunogold labelling on the surface of the bacteria. 


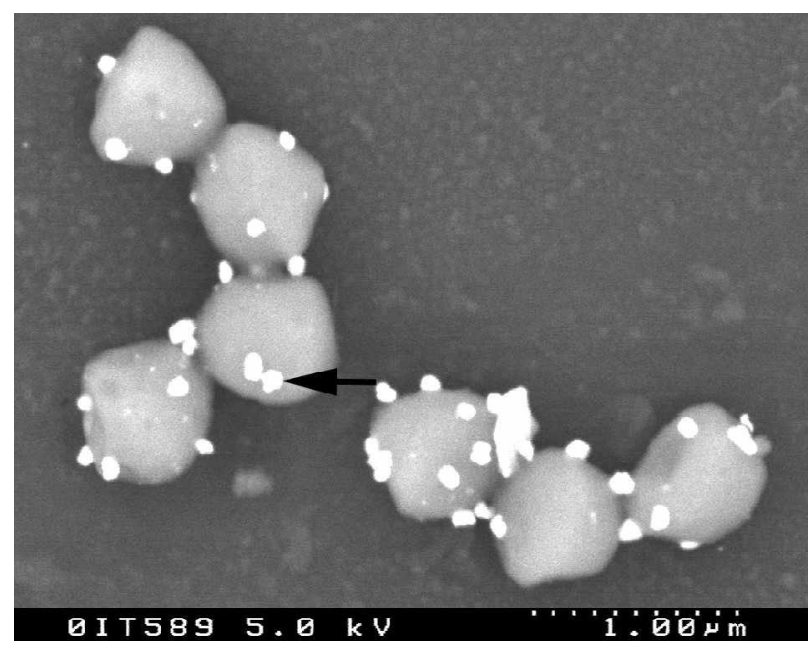

i

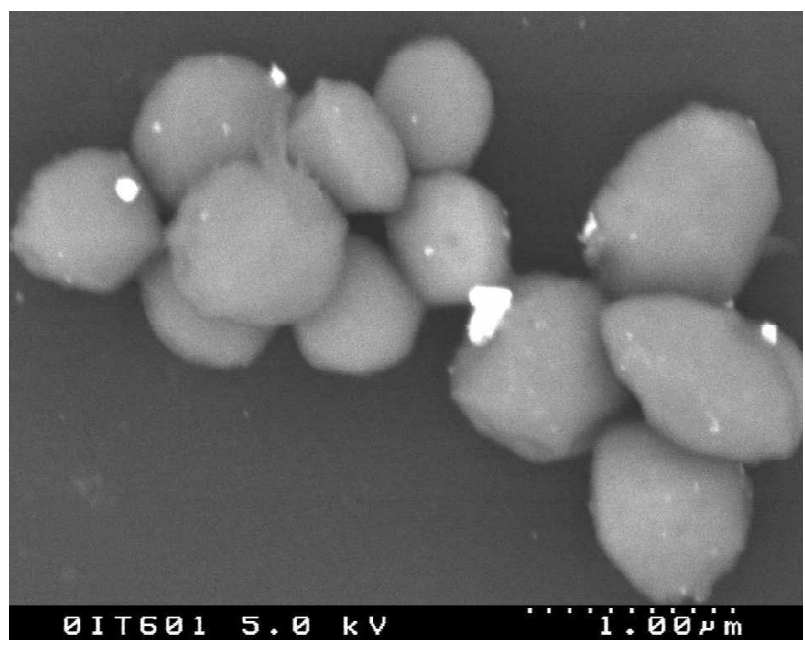

iii

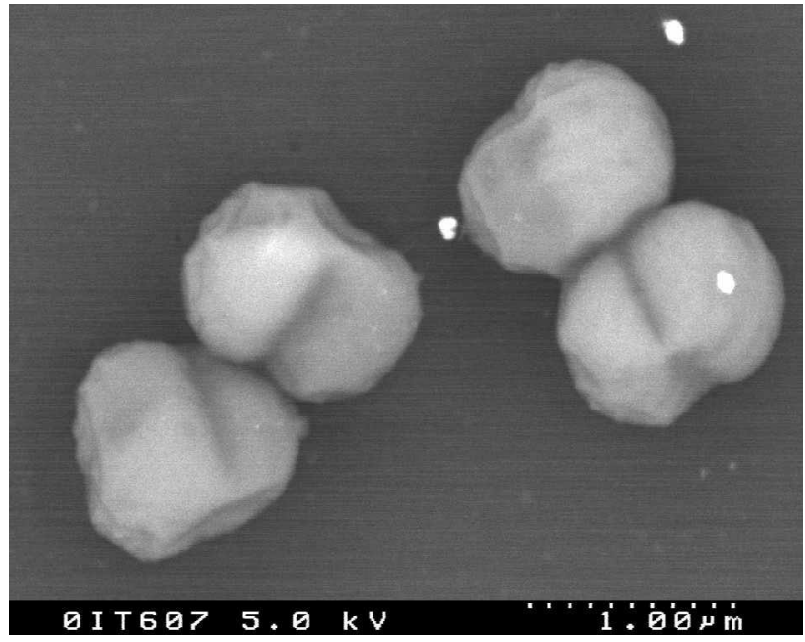

$\mathbf{v}$

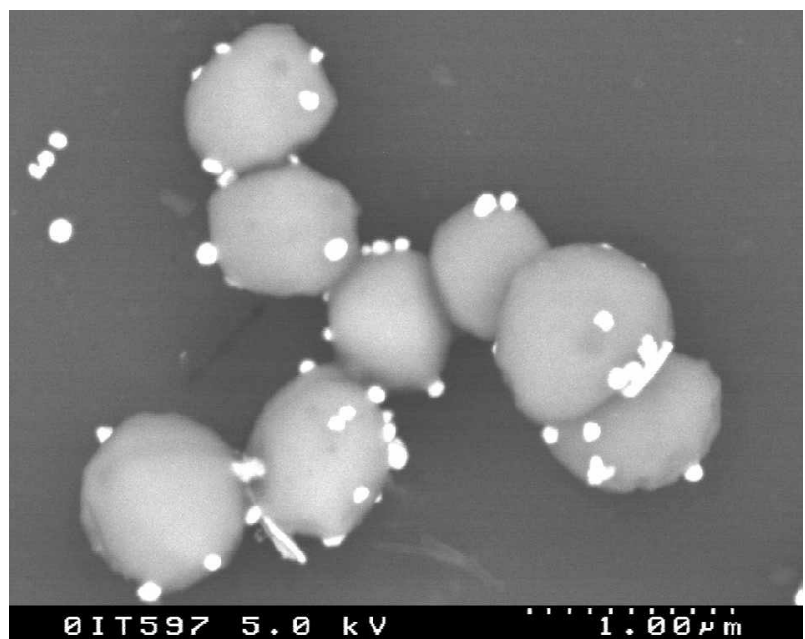

ii

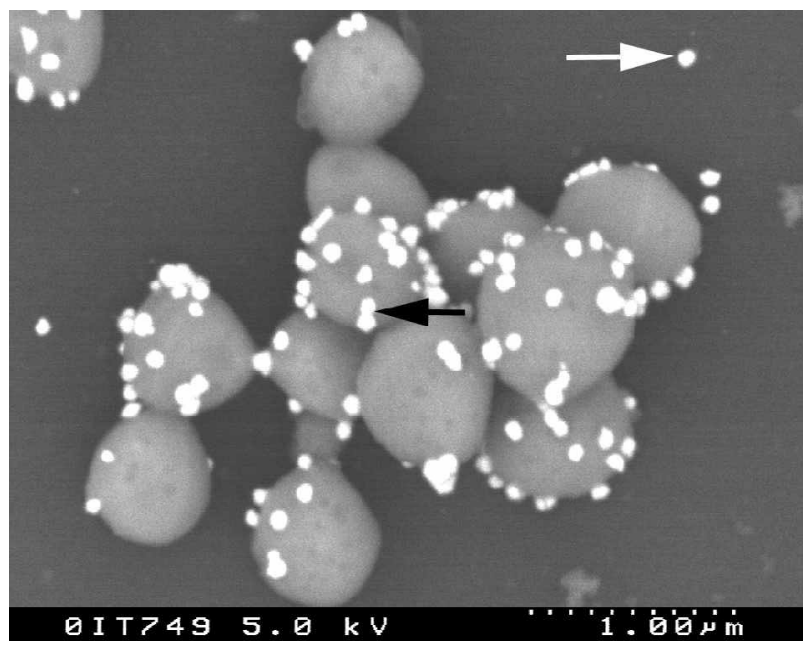

iv

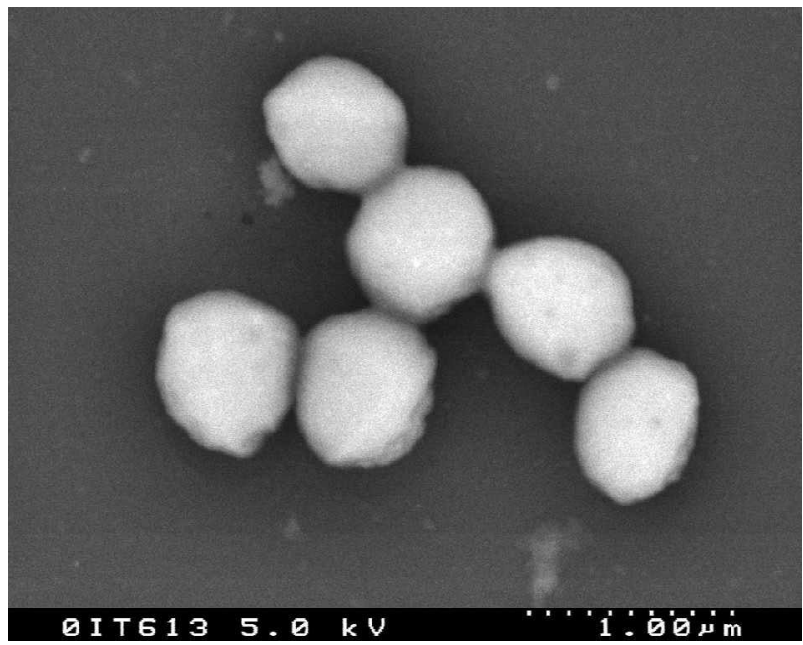

vi

Figure 11. BSE images of $S$. aureus strains grown on Thermanox for 18h, then immunogold labelled with antiClfA, and imaged using Hitachi S-4100 FESEM with accelerating voltage of $5 \mathrm{kV}$, and $40 \mu \mathrm{A}$ emission current. i) S. aureus 8325-4; ii) LH01 (agr spa); iii) LH02 (sarA spa); iv) LH03 (spa); v) LH06 (clfA spa); and vi) Control, LH01 (agr spa), no primary antisera. Black arrows indicate presence of immunogold labelling on the surface of the bacteria. White arrows indicates presence of background labelling. 
proteases, specifically V8 protease (SspA) (Figure 4iii), which is repressed by $\operatorname{sar} A$ (Karlsson et al., 2001). sarA can also down-regulate the production of protein $\mathrm{A}$ at the transcriptional level by binding to the spa promoter (Cheung et al., 1997; 2001). Hence, both agr and sarA are co-regulators for the synthesis of protein $\mathrm{A}$, which is produced in a growth-dependent manner. During growth several bands were observed in $8325-4$ and the mutants which cross-reacted with the anti-ClfA sera (Figure 5ii), but none were as large as expected. These bands were absent in LH04, the clfA negative strain, suggesting that the protein bands observed were ClfA, and were probably broken down into smaller fragments by the activity of a protease, as observed by Hartford et al. (1997). The lanes containing the agr mutant (Figure 5iiB) had more prominent bands than the other strains. Northern blots and expression studies have shown that clfA is transcribed throughout growth (Wolz et al., 1996; Hartford et al., 1997; Wolz et al., 2002). The Western blot in this study (Figure 5ii) also showed the presence of ClfA protein throughout the growth cycle. This suggests that $c l f A$ is partially regulated by the $a g r$ locus, but is also regulated by an agr-independent mechanism, since bands were only observed in the log phase of PC1839 (sar) and PC18391 (agr sar) (Figure 5iii).

Immunocytochemistry was also used to localise protein A and ClfA on the surface of $S$. aureus. The method used was a modification of a method used to label vinculin on fibroblasts (Richards et al., 2001). Immunogold labelling against protein A was seen on the $S$. aureus 8325-4 and mutants with the exception of LH03, spa mutant, indicating that the sera was specific. A monoclonal antibody to protein A of mouse IgG1 isotype was used due to its low non-specific binding of mouse IgG to protein A (Sigma product information, 1998). Sigma found that a polyclonal antibody to protein A produced in rabbits and mice had in addition to Fab antigen binding sites specific for protein A, a significant non-immune Fc binding activity with protein A. Protein A is known to bind to the Fc fragment of IgG (Moks et al., 1986), hence the polyclonal antibody would have resulted in non-specific labelling. During growth, the amount of protein A immunogold labelling observed varied. In early log-phase, immunogold label was observed all over the bacteria, by late-log-phase/ early exponential (4h) the amount of labelling observed decreased, particularly in PC6911 (agr) and PC1839 $(\operatorname{sar} A)$. By stationary phase $(18 \mathrm{~h})$, the amount of label was similar to that seen on bacteria at $2 \mathrm{~h}$. This observation did not follow the trend seen on the Western blots (Figure 3.6), but the difference could be the result of the slightly different culturing method used that had to be used for immunolabelling. The Western blots were the result of liquid cultures rotating, whilst the immunogold labelling involved culturing in a small stationary volume.

Unfortunately, quite a lot of background labelling was observed on these samples despite the blocking procedures. However, this did not have an effect on the results, as labelling was observed on all samples except LH04, the clfA mutant and the control (no primary antibody). For the immunogold labelling of ClfA, the spa mutation was transduced into some of the other strain backgrounds (see
Table 1). The double mutants were constructed so that protein A ordinarily present on the surface would not react with the ClfA antisera during the labelling procedure. Thus, despite the background labelling observed in Figure 9iv, the labelling on LH03 had to be ClfA, as LH03 does not carry the gene, spa. McDevitt et al. (1994) found that ClfA was expressed throughout growth, whereas ClfB is only expressed in the first 2-3h of growth (Hartford et al., 1997). The immunogold labelling in this study partially followed the expected expression pattern seen on Western blots and in the literature (McDevitt et al., 1994, 1995; Hartford et al., 1997; Ni Eidrin et al., 1998), except for the low labelling at $4 \mathrm{~h}$. The reason for this variation is unknown. The differences in expression observed between immunogold labelling and Western blot analysis, could be the result of a modified culturing technique.

An aim of this project was to quantify the amount of adhesins on the surface of $S$. aureus. This could not be done due to the amount of immuno-gold label visualised, and the irregular shape of the silver enhanced gold probes. The irregularity of the silver enhanced gold probes was probably due to the post-fixation using $\mathrm{OsO}_{4}$, which is known to etch the silver enhance used to visualise the $5 \mathrm{~nm}$ gold probes (Owen et al., 2001).

\section{Conclusions}

This study has developed an improved method of extracting covalently bound cell associated proteins, known to be involved in the adherence of $S$. aureus to substrates. By using the FastPrep instrument, purer samples were obtained for SDS-PAGE and Western blot analysis than from using other protein extraction methods (Cheung and Fischetti, 1988; Sugai et al., 1990; Foster, 1992; Navarre et al., 1998). The Western blot analyses confirmed previous observations that cell associated surface proteins are expressed primarily during log phase. It is during exponential growth that $S$. aureus primarily adheres to substrates before the agr locus causes the down-regulation of the surface proteins, and the up-regulation of exoproteins and other virulence determinants. Immunogold labelling of protein A and ClfA was observed all over the bacterial surface and showed no distinct distribution pattern when expressed.

\section{Acknowledgments}

Thanks to Prof. Tim J. Foster, Trinity College, Dublin for the $c l f A$ mutant and ClfA antisera. This study was funded by AO fork grant \#99-F55.

\section{References}

Ames GF, Nikaido, K (1976) Two-dimensional gel electrophoresis of membrane proteins. Biochemistry 15: 616-623.

Arens S, Schlegel U, Printzen G, Ziegler WJ, Perren SM, Hansis M (1996) Influence of materials for fixation 
implants on local infection. An experimental study of steel versus titanium DCP in rabbits. J Bone Joint Surg 78: 647-651.

Baier RE, Meyer AE, Natiella JR, Natiella RR, Carter JM (1984) Surface properties determine bioadhesive outcomes: methods and results. J Biomed Mater Res 18: 337 355 .

Barth E, Myrvik QM, Wagner W, Gristina AG (1989) In vitro and in vivo comparative colonization of Staphylococcus aureus and Staphylococcus epidermidis on orthopaedic implant materials. Biomat 10: 325-328.

Boden MK, Flock JI (1989). Fibrinogen-binding protein/clumping factor from Staphylococcus aureus. Infect Immun 57: 2358-2363.

Boxma H (1995) Wound Infections in Fracture Surgery. Thesis. University of Amsterdam.

Central Public Health Laboratory (2000) Surveillance of surgical site infection - in English hospitals 1997-1999. UK.

Chan PF, Foster SJ (1998) Role of SarA in virulence determinant production and environmental signal transduction in Staphylococcus aureus. J Bacteriol 180: 62326241.

Chang CC, Merritt K (1994) Infection at the site of implanted materials with and without preadhered bacteria. J Orthop Res 12: 526-531.

Cheung AL, Fischetti VA (1988) Variation in the expression of cell wall proteins of Staphylococcus aureus grown on solid and liquid media. Infect Immun 56: 1061-1065.

Cheung AL, Koomey JM, Butler CA, Projan SJ, Fischetti VA (1992) Regulation of exoprotein expression in Staphylococcus aureus, by a locus (sar) distinct from agr. Proc Nat Acad Sci USA. 89: 6462-6466.

Cheung AL, Eberhardt K, Chung E, Yeaman MR, Sullam PM, Ramos M, Bayer AS (1994) Diminished virulence of a sar-/agr- mutant of Staphylococcus aureus in the rabbit model of endocarditis. J Clin Invest 94: 18151822.

Cheung AL, Eberhart K, Heinrichs JH (1997) Regulation of protein A synthesis by the sar and agr loci of Staphylococcus aureus. Infect Immun 65: 2243-2249.

Cheung AL, Schmidt K, Bateman B, Manna AC (2001) SarT, a repressor of alpha-hemolysin in Staphylococcus aureus. Infect Immun 69: 4749-4758.

Cordero J, Munuera L, Folgueira MD (1994) Influence of metal implants on infection- An experimental study in rabbits. J Bone Joint Surg Br 76: 717-720.

Cramton SE, Gerke C, Schnell NF, Nichols WW, Gotz $\mathrm{F}$ (1999) The intercellular adhesion (ica) locus is present in Staphylococcus aureus and is required for biofilm formation. Infect Immun 67: 5427-5433.

Deora R, Misra TK (1996) Characterization of the primary sigma factor of Staphylococcus aureus. J Biol Chem 271: 21828-21834.

Deora R, Tseng T, Misra TK (1997) Alternative transcription factor sigmaSB of Staphylococcus aureus: characterization and role in transcription of the global regulatory locus sar. J. Bacteriol. 179: 6355-6359.

Dickinson GM, Bisno AL (1989) Infections associated with indwelling devices: concepts of pathogenesis; infections associated with intravascular devices. Antimicrob Agents Chemother. 33: 597-601.

Eickhoff TC (1972) Therapy of staphylococcal infection. In: Cohen JO, ed. The Staphylococci. Wiley, New York. pp. 517-541.

Elek S (1956) Experimental staphylococcal infections in the skin of man. Ann NY Acad Sci 65: 85-90.

Elek S D, Conen PE (1957) The virulence of Staphylococcus pyogenes for man: a study of the problems of wound infection. British J Exp Pathol 38: 573-586.

Foster SJ (1992) Analysis of the autolysins of Bacillus subtilis 168 during vegetative growth and differentiation by using renaturing polyacrylamide gel electrophoresis. J Bacteriol 174: 464-470.

Foster SJ (1993) Molecular analysis of three major wall-associated proteins of Bacillus subtilis 168: evidence for processing of the product of a gene encoding a 258 $\mathrm{kDa}$ precursor two-domain ligand-binding protein. Mol Microbiol 8: 299-310.

Foster SJ (1995) Molecular characterization and functional analysis of the major autolysin of Staphylococcus aureus 8325/4. J Bacteriol 177: 5723-5725.

Foster TJ, McDevitt D (1994) Surface-associated proteins of Staphylococcus aureus: their possible role in virulence. FEMS Microbiol Lett 118: 199-206.

Foster TJ, O’Reilly M, Phonimdaeng P, Cooney J, Patel AH, Bramley AJ (1990) Genetic studies of virulence factors of Staphylococcus aureus- Properties of coagulase and gamma-toxin, alpha-toxin, beta-toxin and protein $\mathrm{A}$ in the pathogenesis of $S$. aureus infections. In: Novick RP, ed. Molecular Biology of Staphylococci. VCH Publishing, NewYork. pp 403-420.

François P, Vaudaux P, Foster TJ, Lew DP (1996) Hostbacteria interactions in foreign body infections. Infect Control \& Hospital Epidem 17: 514-520.

Gerber HW, Perren SM (1980) Evaluation of tissue compatibility of in vitro cultures of embryonic bone. In: Winter GD, Leray JL, De Groot K, eds. Evaluation of Biomaterials. Wiley, Chichester, UK. pp 307-314.

Giraudo AT, Raspanti CG, Calzolari A, Nagel R (1994) Characterization of a Tn551-mutant of Staphylococcus aureus defective in the production of several exoproteins. Can J Microbiol 40: 677-681.

Giraudo AT, Cheung AL, Nagel R (1997) The sae locus of Staphylococcus aureus controls exoprotein synthesis at the transcriptional level. Arch Microbiol 168: 53-58.

Giraudo AT, Calzolari A, Cataldi AA, Bogni C, Nagel R (1999) The sae locus of Staphylococcus aureus encodes a two-component regulatory system. FEMS Microbiol Lett 177:15-22

Gristina A (1987) Biomaterial-centered infection: microbial adhesion versus tissue integration. Science 237: 1588-1595.

Gristina A (1994) Implant failure and the immunoincompetent fibro-inflammatory zone. Clin Orthop. 298: 106-118.

Gristina A, Oga M, Webb L, Hobgood C (1985) Adherent bacterial colonization in the pathogenesis of osteomyelitis. Science 228: 990-993.

Gross M, Cramton SE, Gotz F, Peschel A (2001) Key 
role of teichoic acid net charge in Staphylococcus aureus colonization of artificial surfaces. Infect Immun 69: 34233426 .

Gustilo RB, Merkow RL, Templeman D (1990) The management of open fractures. J Bone Joint Surg Am 72: 299-304.

Hanaki H, Labischinski H, Inaba Y, Kondo N, Murakami H, Hiramatsu K (1998) Increase in glutaminenon-amidated muropeptides in the peptidoglycan of vancomycin-resistant Staphylococcus aureus strain Mu50. J Antimicrob Chemother 42: 315-320.

Hartford OM, Francois P, Vaudaux P, Foster TJ (1997) The dipeptide repeat region of the fibrinogen-binding protein (clumping factor) is required for functional expression of the fibrinogen-binding domain on the Staphylococcus aureus cell surface. Mol Microbiol 25: 1065 7106.

Hawiger JS, Timmons S, Strong DD, Cottrell BA, Riley M, Doolittle RF (1982) Identification of a region of human fibrinogen interacting with staphylococcal clumping factor. Biochem. 21: 1407-1413.

Heinrichs JH, Bayer MG, Cheung AL (1996) Characterisation of the sar locus and its interaction with agr in Staphylococcus aureus. J Bacteriol 178: 418-423.

Herrmann M, Lai QJ, Albrecht RM, Mosher DF, Proctor RA (1993) Adhesion of Staphylococcus aureus to surface-bound platelets: role of fibrinogen/ fibrin and platelet integrins. J Infect Dis 167: 312-322.

Hiramatsu K (1995) Molecular evolution of MRSA. Microbiol Immunol 39: 531-543

Hiramatsu K (2001) Vancomycin-resistant Staphylococcus aureus: a new model of antibiotic resistance. Lancet Infect Dis 1: 147-155.

Hiramatsu K, Hanaki H, Ino T, Yabuta K, Oguri T, Tenover FC (1997) Methicillin-resistant Staphylococcus aureus clinical strain with reduced vancomycin susceptibility \{letter\}. J Antimicrob Chemother 40: 135-136.

Horsburg MJ, Aish JL, White IJ, Shaw L, Lithgow JK, Foster SJ (2002) $\mathrm{s}^{\mathrm{B}}$ modulates virulence determinant expression and stress resistance: characterisation of a functional $r s b U$ strain derived from Staphylococcus aureus 8325-4. J Bacteriol 184: 5457-5467

Howard BJ, Kloos WE (1987) Staphylococci. In: Howard BJ, Klass J II, Rubin SJ, Weissfeld AS, Tilton RC, eds. Clinical and Pathogenic Microbiology. Mosby, Washington D.C. pp 231-244

Hoyle BD, Costerton JW (1991) Bacterial resistance to antibiotics: the role of biofilms. Prog Drug Res 37: 91105.

Jevons MP (1961) Celbenin - resistant staphylococci. Brit Med J 1: 124.

Karlsson A, Saravia-Otten P, Tegmark K, Morfeldt E, Arvidson S (2001) Decreased amounts of cell wall-associated protein A and fibronectin- binding proteins in Staphylococcus aureus sarA mutants due to up- regulation of extracellular proteases. Infect Immun 69: 4742-4748.

Karakawa WW, Vann WF (1982) Capsular polysaccharides of Staphylococcus aureus. Semin Infect Dis 4: 285-293.

Klein JO, Finland M (1963) The new penicillins. New
Engl J Med 269:1019-1025.

Kloos WE, Bannerman TL (1994) Update on clinical significance of coagulase-negative staphylococci. Clin Microbiol Rev 7: 117-140.

Kloos WE, Lambe DW Jr (1991) Staphylococcus. In: Barlows A, Hausler WJ, Herrmann KL, Isenberg HD, Shadomy HJ, eds. Manual of Clinical Microbiology, $5^{\text {th }}$ ed. ASM, Washington, D.C. pp 222-237.

Kloos WE, Musselwhite MS (1975) Distribution and persistence of Staphylococcus and Micrococcus species and other aerobic bacteria on human skin. Appl Microbiol 30: 381-385.

Kloos WE, Schleifer KH (1986) Genus IV - Staphylococcus Rosenbach 1884. In: Sneath PHA, Mair NS, Sharpe ME, eds. Bergey's Manual of Systemic Bacteriology, Vol 2. Williams and Wilkins, Baltimore.

Knox KW, Wicken AJ (1973) Immunological properties of teichoic acids. Bacteriol Rev 37: 215-257.

Kornblum J, Kreiswirth BN, Projan SJ, Ross H, Novick RP (1990) Agr: a polycistronic locus regulating exoprotein synthesis in Staphylococcus aureus. In: Novick RP, ed. Molecular Biology of Staphylococci. VCH Publishing, New York. pp 373-403.

Kuroda M, Ohta T, Uchiyama I, Baba T, Yuzawa H, Kobayashi I, Cui L, Oguchi A, Aoki K, Nagai Y, Lian J, Ito T, Kanamori M, Matsumaru H, Maruyama A, Murakami H, Hosoyama A, Mizutani-Ui Y, Takahashi NK, Sawano T, Inoue R, Kaito C, Sekimizu K, Hirakawa H, Kuhara S, Goto S, Yabuzaki J, Kanehisa M, Yamashita A, Oshima K, Furuya K, Yoshino C, Shiba T, Hattori M, Ogasawara N, Hayashi H, Hiramatsu K (2001) Whole genome sequencing of methicillin-resistant Staphylococcus aureus. Lancet 357: 1225-1240.

Laemmli UK (1970) Cleavage of structural proteins during the assembly of the head of bacteriophage T4. Nature 227: 680-685.

Lindberg M, Jönsson K, Müller H, Jonsson H, Signas C, Höök M, Raja R, Raucci G, Anantharamaiah GM (1990) Fibronectin-binding proteins in Staphylococcus aureus. In: Novick RP, ed. Molecular Biology of Staphylococci. VCH Publishing, New York. pp 343-356.

Lindsay J, Foster SJ (1999) Interactive regulatory pathways control virulence determinant production and stability in response to environmental conditions in Staphylococcus aureus. Mol Gen Genet 262: 323-331.

Lowy FD (1998) Is Staphylococcus aureus an intracellular pathogen. Trends Microbiol 8: 341-344.

Manna AC, Bayer MG, Cheung AL (1998) Transcriptional analysis of different promoters in the sar locus in Staphylococcus aureus. J Bacteriol 180: 3828-3386.

Mazmanian SK, Ton-That H, Schneewind O (2001) Sortase-catalysed anchoring of surface proteins to the cell wall of Staphylococcus aureus. Mol Microbiol 40: 10491057.

McDevitt D, Francois P, Vaudaux P, Foster TJ (1994) Molecular characterization of the clumping factor (fibrinogen receptor) of Staphylococcus aureus. Mol Microbiol 11: 237-248.

McDevitt D, Francois P, Vaudaux P, Foster TJ (1995) Identification of the ligand-binding domain of the surface- 
located fibrinogen receptor (clumping factor) of Staphylococcus aureus. Mol Microbiol 16: 895-907.

Melcher GA, Claudi B, Schlegel U, Perren SM, Printzen G, Munzinger J (1994) Influence of type of medullary nail on the development of local infection. An experimental study of solid and slotted nails in rabbits. $J$ Bone Joint Surg 76: 955-959.

Merritt K, Dowd JD (1987) Role of internal fixation in infection of open fractures: studies with Staphylococcus aureus and Proteus mirabilis. J Ortho Res 5: 23-28.

Moks T, Abrahmsen L, Nilsson B, Hellman U, Sjöquist J, Uhlén M (1986) Staphylococcal protein A consists of five IgG-binding domains. Eur J Biochem 156: 637-643.

Moran CP (1993) RNA polymerase and transcription factors. In: Sonenshein AL, Hoch JA, Losick R, eds. Bacillus subtilis and other Gram-positive bacteria. American Society of Microbiology, Washington, D.C. pp 653667.

Morfeldt E, Janzon L, Arvidson S, Löfdahl S (1988) Cloning of a chromosomal locus (exp) which regulates the expression of several exoprotein genes in Staphylococcus aureus. Mol Gen Genet 211: 435-440.

Morris A, Kellner JD, Low DE (1998) The superbugs: evolution, dissemination and fitness. Curr Opin Microbiol 1: $524-529$.

Navarre WW, Ton-That H, Faull KF, Schneewind O (1998) Anchor structure of staphylococcal surface proteins. II. COOH-terminal structure of muramidase and amidase-solubilized surface protein. J Biol Chem 273: 29135-29142.

Navarre WW, Schneewind O (1999) Surface proteins of gram-positive bacteria and mechanisms of their targeting to the cell wall envelope. Microbiol Mol Biol Rev 63: 174-229.

Ni Eidhin D, Perkins S, Francois P, Vaudaux P, Höök M, Foster TJ (1998) Clumping factor B (ClfB), a new surface-located fibrinogen-binding adhesin of Staphylococcus aureus. Mol Microbiol 30: 245-257.

Owen GR, Meredith DO, ap Gwynn I, Richards RG (2001) Enhancement of immunogold-labelled focal adhesion sites in fibroblasts cultured on metal substrates: problems and solutions. Cell Biol Int 25: 1251-1259.

Pashley RM, McGuiggan PM, Ninham BW, Evans DF (1985) Attractive forces between uncharged hydrophobic surfaces: direct measurements in aqueous solution. Science 229: 1088-1089.

Patti JM, Allen BL, McGavin MJ, Höök M (1994) MSCRAMM-mediated adherence of microorganisms to host tissues. Ann Rev Microbiol 48: 585-617.

Perren SM (1991) The concept of biological plating using the limited contact-dynamic compression plate (LCDCP). Scientific background, design and application. Injury 22 Suppl 1: 1-41.

Peterson PK, Verhoef J, Quie PG (1977) Influence of temperature on opsonization and phagocytosis of staphylococci. Infect Immun 15: 175-179.

Petty W, Spanier S, Shuster JJ, Silverthorne C (1985) The influence of skeletal implants on incidence of infection- Experiments in a canine model. J Bone Joint Surg 67: 1236-1244.
Projan SJ, Novick RP (1997) The molecular basis of pathogenicity. In: Crossley KB, Archer GL, eds. The Staphylococci in Human Diseases. Churchill Livingston, London. pp 55-81.

Recsei P, Kreiswirth B, O'Reilly M, Schlievert P, Gruss A, Novick RP (1986) Regulation of exoprotein gene expression in Staphylococcus aureus by agr. Mol Gen Genet 202: $58-61$.

Richards RG, ap Gwynn I (1995) Backscattered electron imaging of the under-surface of resin-embedded cells by field emission scanning electron microscopy. J Microsc 177:43-52.

Richards RG, Stiffanic M, Owen GR, Riehle M, ap Gwynn I, Curtis AS (2001) Immunogold labelling of fibroblast focal adhesion sites visualised in fixed material using scanning electron microscopy, and living, using internal reflection microscopy. Cell Biol Int 25: 12371249.

Ruoslahti E (1991) Integrins as receptors for extracellular matrix. In: Hay ED, ed. Cell Biology of Extracellular Matrix. Plenum Press, NewYork. pp 343-363.

Schindler CA, Schuhardt VT (1964) Lysostaphin: a new bacteriologic agent for the staphylococcus. Proc Natl Acad Sci US 51: 414.

Schmidt KA, Manna AC, Gill S, Cheung AL (2001) SarT, a repressor of alpha-hemolysin in Staphylococcus aureus. Infect Immun 69: 4749-4758.

Schneewind O, Fowler A, Faull KF (1995) Structure of the cell wall anchor of surface proteins in Staphylococcus aureus. Science. 268: 103-106.

Shockman GD, Barrett JF (1983) Structure, function, and assembly of cell walls of gram-positive bacteria. Annu Rev Microbiol 37: 501-527.

Shulman JA, Nahmias AJ (1972) Staphylococcal infections: clinical aspects. In: Cohen JO, ed. The Staphylococci. Wiley, New York pp 457-482.

Sievert DM, Boulton ML, Stoltman G, Johnson D, Stobierski MG, Downes FP, Somsel PA, Rudrik JT (2002) Staphylococcus aureus resistant to vancomycin - United States, 2002. MMWR 51:565-567

Stickler DJ, McLean RJC (1995) Biomaterials associated infections: the scale of the problem. Cells Mater 5: 167-182.

Sugai M, Akiyama T, Komatsuzawa H, Miyake Y, Suginaka H (1990) Characterisation of sodium dodecyl sulfate-stable Staphylococcus aureus: bacteriolytic enzymes by polyacrylamide gel electrophoresis. J Bacteriol 172: 6494-6498.

Tegmark K, Karlsson A, Arvidson S (2000) Identification and characterization of SarH1, a new global regulator of virulence gene expression in Staphylococcus aureus. Mol Microbiol 37: 398-409.

Thakker M, Park JS, Lee JC (1998) Staphylococcus aureus serotype 5 capsular polysaccharide is antiphagocytic and enhances bacterial virulence in a murine bacteraemia model. Infect Immun 66: 5183-5189.

Ton-That H, Faull KF, Schneewind O (1997)Anchor structure of staphylococcal surface proteins. A branched peptide that links the carboxyl terminus of proteins to the cell wall. J Biol Chem 272: 22285-22292. 
Ton-That H, Liu G, Mazmanian SK, Faull KF, Schneewind O (1999) Purification and characterization of sortase, the transpeptidase that cleaves surface proteins of Staphylococcus aureus at the LPXTG motif. Proc Natl Acad Sci USA 96: 12424-12429.

Waldvogel FA (1990) Staphylococcus aureus (including toxic shock syndrome), In: Mandell GL, Douglas RG, Bennett JE (eds.). Principles and Practice of Infectious Disease, $3^{\text {rd }}$ d. Churchill Livingston, London. pp 1489 1510 .

Walenkamp GH (1989) Bacterial joint infections: a retrospective study for the source of infection. Ned Tijdschr Geneeskd. 133: 2143-2144.

Wallmark G, Finland M (1961) Phage types and antibiotic susceptibility of pathogenic staphylococci: results at Boston City hospital 1959- 1960 and comparisons with strains of previous years. J Am Med Assoc 175: 886-897. Walsh CT (1993) Vancomycin resistance: decoding the molecular logic. Science 261: 308-309.

Wilkinson BJ (1997) Biology. In: Crossley KB, Archer GL, eds. The Staphylococci in Human Diseases. Churchill Livingston, London. pp 1-38.

Wilkinson BJ, Holmes KM (1979) Staphylococcus aureus cell surface: capsule as a barrier to bacteriophage adsorption. Infect Immun 23: 549-552.

Williams DF (1989) A model for biocompatibility and its evolution. J Biomed Eng 11:185-192

Wolz C, McDevitt D, Foster TJ, Cheung AL (1996) Influence of agr on fibrinogen binding in Staphylococcus aureus Newman. Infect Immun 64: 3142-3147.

Wolz C, Goerke C, Landmann R, Zimmerli W, Fluckiger U (2002) Transcription of clumping factor a in attached and unattached Staphylococcus aureus in vitro and during device-related infection. Infect Immun 70: 2758-2762.

Woodward SC, Salthouse TN (1986) The tissue response to implants and its evaluation by light microscopy. In: von Recum AF, ed. Handbook of Biomaterial Evaluation. Collier Macmillan, London. pp 364-378.

Worlock P, Slack R, Harvey L, Mawhinney R (1994) The prevention of infection in open fractures: an experimental study of the effect of fracture stability. Injury $\mathbf{2 5}$ : 31-38.

\section{Web References}

Web ref. 1 Oklahoma, S. aureus 8325 (26 Aug. 02) www.genome.ou.edu/staph.html

Web ref. 2 TIGR $S$. aureus COL (26 Aug. 02)

http://www.tigr.org/tigr-scripts/CMR2/

GenomePage3.spl?database $=$ gsa

Web ref. 3 S. aureus MRSA and MSSA (28 Oct. 02) www.sanger.ac.uk/Projects/S_aureus/

Web ref. 4 Japanese $S$. aureus N315 (26 Aug. 02) http://www.bio.nite.go.jp/cgi-bin/dogan/ genome_top.cgi?'n315'
Web ref. 5 Japanese $S$. aureus Mu50 (26 Aug. 02)

http://w3.grt.kyushu-u.ac.jp/VRSA

Web ref. 6 TIGR $S$. aureus MW2 (06 Nov. 02)

http://www.tigr.org/tigr-scripts/CMR2/

GenomePage3.spl?database $=$ ntsa03

\section{Discussion with Reviewers}

P. Lambert: The images give a very clear impression of the microbial cells and surface localisation on the antigen. Some clumping of the immunogold label has occurred during amplification, would this be reduced by use of different amplification methods?

Authors: One reason for the clumping of immunogold is that the amplification time was too long, a shorter silver enhancement time would have decreased this problem. A second possible solution is to use gold enhancement which results in smaller amplification of the immunolabel and has two other advantages, it is not etched by osmium tetroxide and secondly if one is studying $S$. aureus adhesion to a metal implant gold enhancement does not react with the metal implant unlike the silver enhancement (Owen et al., 2001).

P. Lambert: Production of exocellular polysaccharide is a prominent feature of microbial biofilms, especially in infections associated with medical devices. Would the authors predict that their EM methods would work with cells grown as mature biofilms or on clinical specimens? Authors: Mature biofilms could be visualised using the fixation techniques mentioned, however the immunolabelling technique would not work so well due to the presence of the exocellular polysaccharide which could prevent the antibodies reaching their target antigen. The problem with a clinical specimen would be to ensure that the bacteria had adhered to the biomaterial, otherwise maybe a transmission electron microscopy method of immunolabelling could be used with a suspension.

D. Stickler: Why use aerated cultures for preparation of the cells that were examined by Western blotting and static cultures for the culture of immunogold-labelling?

Authors: The protocol used for the Western blot followed a published conventional microbiology methods and the protocol used for the immunogold labelling followed the methodology used for immunolabelling fibroblast cells (Richards et al., 2001). This is a good suggestion for future studies to develop the immunolabelling technique for aerated cultures.

D. Stickler: The levels of background staining in the immunogold labelling are a cause for concern, even though the authors follow all the conventional attempts to prevent this in the blocking steps used in their protocol. The background persists, particularly in Figure 9 where it makes interpretation difficult. Interpretation would be 
easier if additional control staining had been carried out for comparison. The only controls illustrated involved omission of the primary antibody. This only permits assessment of any non-specific signal attributable to the subsequent application of the second antibody. Could the authors comment on the requirement for further controls to detect any non-specific binding by the primary antibody itself?

Authors: Mutant strains which were defective in the antisera used i.e. LH03, spa defective and LH04, clfA defective were used as controls. These two strains cannot bind the antibodies used because the bacteria do not have an active receptor to the antibodies. Double mutants were used in the ClfA immunolabelling method to prevent the binding of the ClfA antibodies nonspecifically to Protein A. The high level of background on the substrate could be due to nonspecific binding to residue material remaining from the culture media, however the controls showed very low background labelling on the bacteria themselves.

D. Stickler: The authors comment that the gold labelling was non-uniform and irregular. They were of course imaging the silver-enhanced gold marker and not the gold particles directly. Have the authors considered that epitope distribution may be quite different between the $S$. aureus strains? Figure 6i compared to 6ii shows relative few large silver/gold deposits. Does this represent tight grouping of protein A on the cell surface of the wild type. Variation in the density of epitope distribution across the cells may not have been immunogold labelled with equal sensitivity by the $5 \mathrm{~nm}$ gold conjugate due to steric hindrance. Did the authors consider using $1 \mathrm{~nm}$ gold labelled secondary antibody to improve the sensitivity and resolution of the method?
Authors: There is a possibility that there are different epitope distributions between the strains, but this was not noticeable in this study. The reason for more labelling on Figure 6ii, agr mutant compared to 6i, wild-type is that the agr mutant is known to express more surface proteins, such as protein A, compared to the wild-type. Previous work with fibroblasts from this group showed better sensitivity compared to $1 \mathrm{~nm}$ gold, since not all $1 \mathrm{~nm}$ gold particles enhanced. The authors believe this is due to the antibody wrapping around the gold particle preventing contact with enhancement solutions. The authors agree that the larger the gold label used, the higher is the degree of steric hindrance.

A. Eley: In the review section of the paper the authors comment on differences in infection rates between stainless steel and titanium implants. Does titanium not have antimicrobial activity?

Authors: In the studies of Arens et al. (1996) and Melcher et al. (1994), from the AO Research Institute, they saw that a lower amount of bacteria was required to cause infection with titanium implants compared to stainless steel implants, which we believe was probably due to the extreme difference in microtopography of the surfaces of the two materials. As the reviewer mentions, studies have shown that titanium dioxide in the presence of sunlight or UV light is toxic to micro-organisms in contact with the surface (Industrial Research Ltd., www.irl.cri.nz/mattech-group/project_area_profiles/antimicrobialsurfaces.html). However, all orthopaedic implants are sterilised before use, therefore infections do not come from the implants. To the authors' knowledge, titanium has no antimicrobial activity within a body. 